\title{
FEEDING ECOLOGY OF THE FRANCISCANA (PONTOPORIA BLAINVILLEI) IN MARINE AND ESTUARINE WATERS OF ARGENTINA
}

\author{
Diego Rodríguez ${ }^{(1)}$, Laura Rivero $^{(1)}$ and Ricardo Bastida ${ }^{(1)}$
}

\begin{abstract}
Stomach contents of 110 franciscanas (Pontoporia blainvillei), from northern Argentina were analysed in order to improve our knowledge about the feeding habits of this species and to better characterise the lactation period. The samples included calves, juveniles and adults of both sexes. Evidence of predation by franciscanas is seen at a very young age (2.5-3 months), with a transition diet composed by both milk and solid food, mainly represented by crustaceans. Weaning seems to begin by April, when franciscanas are about 6-7 months old. Franciscanas inhabiting two different habitats were analysed in this study: a brackish water estuary and an adjacent marine coastal system. The diet of Pontoporia blainvillei in northern Argentina was composed by a total of 26 prey species: 20 teleosts, 4 crustaceans and 2 cephalopods. Based on the Index of Relative Importance (IRI) the main prey species were Cynoscion guatucupa, Micropogonias furnieri, Loligo sanpaulensis and Urophycis brasiliensis. Estuarine franciscanas preyed mainly on Micropogonias furnieri (dominant species), Cynoscion guatucupa, Odonthestes argentinensis and Macrodon ancylodon, while dolphins from marine areas preyed mainly on Cynoscion guatucupa (dominant species), Loligo sanpaulensis and Urophycis brasiliensis. Our results confirm that franciscanas prey mainly on juvenile fish $(<8 \mathrm{~cm})$ and small loliginid squids, in close agreement with previous results obtained in southern Brazil and Uruguay. Qualitative and quantitative differences observed in the diet of dolphins from each habitat emphasise the need to discriminate between samples from different habitats and environmental parameters.
\end{abstract}

Resúmen - Se analizaron 110 contenidos estomacales de franciscanas (Pontoporia blainvillei) provenientes de la costa norte de Argentina, para extender en conocimiento sobre su dieta y caracterizar la lactancia. Las muestras incluyeron cachorros, juveniles y adultos de ambos sexos. Las primeras etapas de predación se inician a muy temprana edad (2,5-3 meses), presentando una dieta de transición compuesta tanto por leche como por presas sólidas, principalmente crustáceos; el destete se iniciaría a partir de abril, a una edad estimada entre 6 y 7 meses. Las franciscanas estudiadas provienen de dos habitats diferentes: un área estuarial de baja salinidad y la region marina adyacente. La dieta de Pontoporia blainvillei de Argentina estuvo compuesta por un total de 26 especies: 20 teleósteos, 4 crustáceos y 2 cefalópodos. Basados en el Indice de Importancia Relativa (IIR), las presas más importantes fueron Cynoscion guatucupa, Micropogonias furnieri, Loligo sanpaulensis y Urophycis brasiliensis. Las franciscanas provenientes del área estuarial predaron principalmente sobre Micropogonias furnieri (especie dominante), Cynoscion guatucupa, Odonthestes argentinensis y Macrodon ancylodon, mientras que los delfines marinos predaron sobre Cynoscion guatucupa (especie dominante), Loligo sanpaulensis y Urophycis brasiliensis. Nuestros resultados confirman que la franciscana preda sobre peces juveniles $(<8 \mathrm{~cm})$ y pequeños calamares Loliginidae, coincidiendo con resultados previos obtenidos en el sur del Brasil y Uruguay. Las diferencias cualitativas y cuantitativas observadas en la dieta de cada uno de las áreas analizadas, nos sugieren que los futuros estudios sobre ecología trófica de la franciscana deberían discriminarse de acuerdo al origen de los ejemplares y a la tipificación del ambiente.

Keywords: Franciscana, feeding ecology, incidental captures, estuary, lactation.

\section{Introduction}

The study of diet and food habits of marine mammals are important, not only to understand the biology of this group, but also to evaluate their role in marine ecosystems and quantify the interaction with fisheries. In the case of the franciscana (Pontoporia blainvillei) these studies are of particular interest because interactions with fisheries are widely recorded (e.g. Brownell, 1989; Praderi et al., 1989; Corcuera, 1994; Pinedo, 1994; Secchi et al., 1997) and many prey items are of commercial importance and subject to overfishing (Bastida et al., in press).

Because of their small size, early reproduction and limited energy stores (Brownell, 1989), franciscanas probably must limit their movements to areas where food resources are concentrated. Feeding ecology studies are fundamental to expand our knowledge of the dynamics between Pontoporia and their prey. Most of the studies performed on Pontoporia are based on juveniles and adults incidentally killed in gillnets (e.g. Bassoi, 1997; Ott, 1994), with limited information available for calves because they are rarely entangled (e.g. Secchi et al., 1997). As a consequence, the lactation period and the development during the first year of life is still one of the least known aspects of the life history of franciscana. The frequent record of calves in northern Argentina (Bastida et al., 1996; Loureiro et al., 1996) allowed us the opportunity to study the feeding ecology of Pontoporia calves and examine the ontogenetic variation in their diet. The main objectives of the present study were to qualify and quantify in detail the diet of franciscanas from the northern coast of Argentina, where two distinct habitats are found: the wide La Plata River estuary and the adjacent marine coastal area. The lactation period and the transition to solid feeding was characterised and compared with feeding habits of juveniles and adults. A comparison between both habitats was of particular interest to determine if those habitats influenced the feeding habits of franciscanas.

\section{Material and Methods}

We analysed 110 stomach contents of franciscanas from the northern coast of Argentina. The dolphins were incidentally killed in gillnets or found stranded in the external area of the Rio de la Plata estuary and the southern marine area from 1992 to 2000 (Figure 1; Table 1). For each specimen

\footnotetext{
${ }^{1}$ Consejo Nacional de Investigaciones Científicas y Técnicas (CONICET), and Departamento de Ciencias Marinas, Facultad de Ciencias Exactas y Naturales, Universidad Nacional de Mar del Plata. Casilla de Correo 43, (7600) Mar del Plata, Argentina.

- Corresponding author: dhrodri@mdp.edu.ar
} 


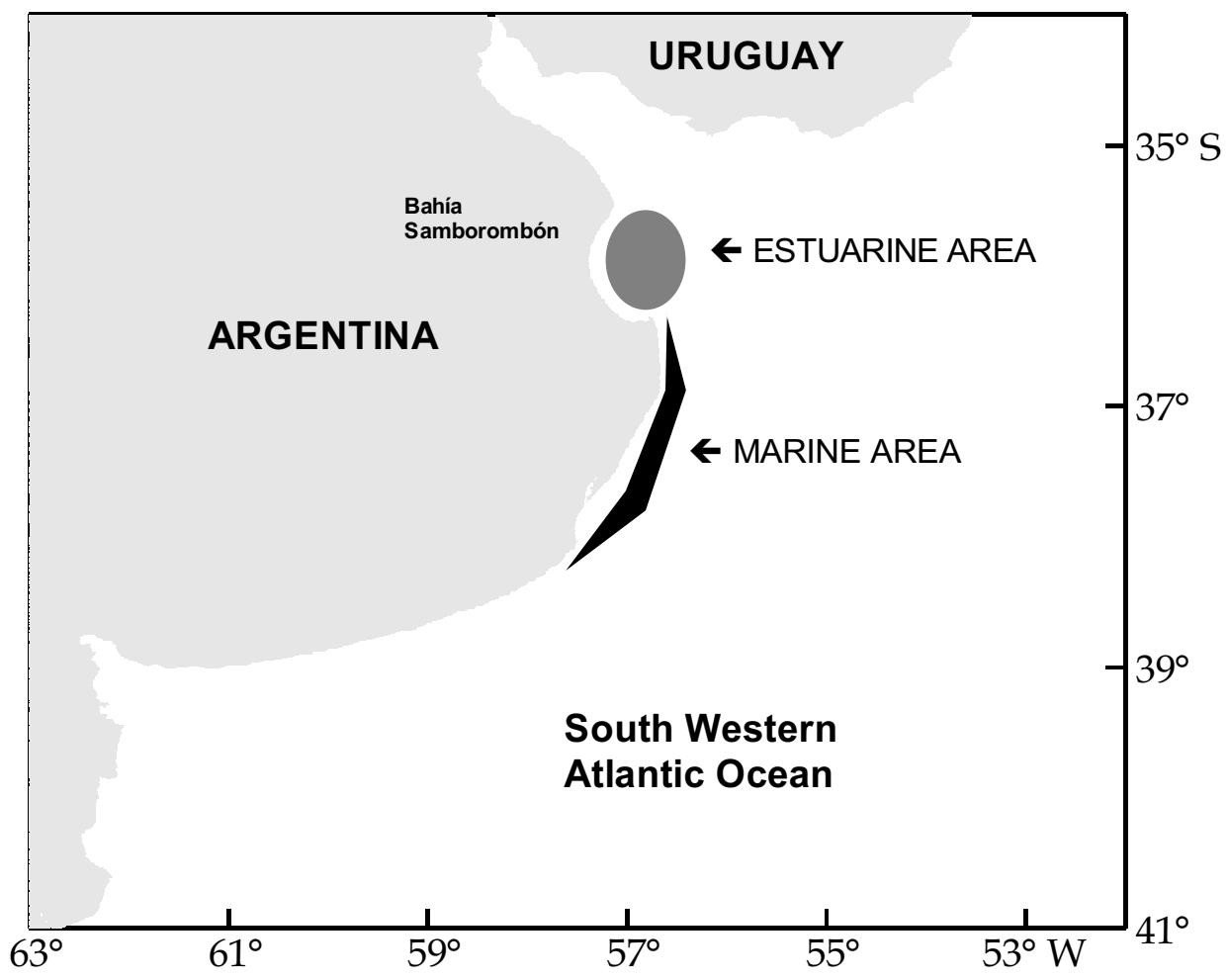

Figure 1. Map of the study site, with indication of estuarine and marine areas.

Table 1. List of stomach contents of the franciscanas analysed in the present study. Juveniles and adults are discriminated between animals from marine $(\mathrm{M})$ and estuarine $(\mathrm{E})$ habitats.

\begin{tabular}{lccccc}
\hline \hline Sex & Suckling Calves & Transition Calves & Weaned Calves & Juveniles and Adults (M/E) & Total \\
\hline \hline Males & 14 & 8 & 8 & $29(11 / 18)$ & 59 \\
Females & 8 & 5 & 4 & $22(10 / 12)$ & 39 \\
Undetermined & -- & 1 & 2 & $9(6 / 3)$ & 12 \\
Total & 22 & 14 & 14 & $60(27 / 33)$ & 110 \\
\hline \hline
\end{tabular}

sex, body weight and external measurements were taken following Norris (1961).

Stomachs, including all the chambers, were excised and frozen for later analysis. A total of 4768 otoliths $(=3143$ specimens), 722 cephalopod mandibles (beaks; 460 specimens) and remains of 428 crustaceans were found. Prey items were identified to the lowest possible taxon with the aid of a laboratory reference collection (Grupo de Mamíferos Marinos, Universidad Nacional de Mar del Plata, Argentina). Identification efficiency was high, as 95\% of the otoliths, $99 \%$ of the beaks and $96 \%$ of the crustacean remains were identified.

Relative prey importance was determined by the Frequence of Occurrence (FO\%, the percentage of stomach contents in which a prey taxon occurred), Numerical Abundance $(\mathrm{N} \%$, the percentage of occurrences of each prey taxon from a tally of occurrences from all prey taxa found) and Biomass (W\%, the percentage of biomass contributed by each prey to the total biomass). The Index of Relative Importance (IRI) of Pinkas et al. (1971), with the Castley et al. (1991) volumetric modification (IRI = $\left.\left[(\mathrm{N} \%+\mathrm{W} \%){ }^{*} \mathrm{FO} \%\right]\right)$, was computed and later recalculated as the Percentage IRI, following Cortés (1997).

Reconstituted biomass of fish was calculated from otolith length-fish length and length-weight curves developed by Grupo de Mamíferos Marinos (Universidad Nacional de Mar del Plata, Argentina) and from the literature (Table 2). The franciscanas studied were classified into four categories, according to feeding regime:

1. Suckling Calves: those dolphins with only traces of milk found in the stomachs. Within this category different subcategories were considered according of the presence and absence of umbilical cord (neonates and non-neonates). As umbilical cord in rehabilitated calves is lost within 48 to 72 hours (Loureiro et al., 1996), we estimated these calves to be less than one 
week old. In our study we only considered as newborns those dolphins found alive and with traces of milk in their stomach, in order to avoid including possible aborted foetuses.

2.Transition Calves: those dolphins with both traces of milk and solid food items macroscopically found in the stomachs. The term transition was applied assuming that these animals were in the transition stage between lactation and the onset of solid food intake.

3. Weaned Calves: those franciscanas less than one year old (total length $\leq 105 \mathrm{~cm}$; Kasuya and Brownell, 1979) that consumed only solid prey.

4. Juveniles and Adults: those dolphins older than one year, in which only solid food remains were found.
For the assessment of body condition, total blubber weight and liver weight of incidentally killed or stranded franciscanas were recorded and expressed as a percentage of body weight (Fat and Liver Indexes). The Relative Index of Body Condition (Kn) of Le Cren (1951) was calculated:

$$
\mathrm{Kn}=\mathrm{Wo} / \mathrm{We}
$$

where

$$
\begin{aligned}
& \text { Wo = Recorded Body Weight }(\mathrm{kg}) \\
& \text { We = Estimated Body Weight }(\mathrm{kg}) \\
& \text { from the length-weight curve. }
\end{aligned}
$$

For this study we estimated the length-weight curve from

\begin{tabular}{|c|c|c|c|c|c|}
\hline Teleosts & Regressions & $\mathrm{N}=$ & $\mathrm{r}^{2}$ & Size Range $(\mathrm{cm})$ & Source \\
\hline \multirow{3}{*}{ Micropogonias furnieri } & $\mathrm{TL}=-3.327+20.328 \mathrm{OL}$ & 48 & 0.918 & \multirow{3}{*}{$25-67$} & \multirow{3}{*}{ Present study } \\
\hline & $\mathrm{W}=4.340 \mathrm{e}^{-6} \mathrm{TL}^{3.157}$ & 77 & 0.997 & & \\
\hline & $\mathrm{W}=0.053 \mathrm{OL}^{3.283}$ & 77 & 0.994 & & \\
\hline \multirow{3}{*}{ Cynoscion guatucupa } & $\mathrm{TL}=-3.217+19.133 \mathrm{OL}$ & 44 & 0.977 & \multirow{3}{*}{$6-19$} & \multirow{3}{*}{ Present study } \\
\hline & $\mathrm{W}=2.282 \mathrm{e}^{-5} \mathrm{TL}^{2.8375}$ & 44 & 0.997 & & \\
\hline & $\mathrm{W}=0.0895 \mathrm{OL}^{2.8480}$ & 44 & 0.992 & & \\
\hline \multirow{3}{*}{ Odonthestes argentinensis } & $\mathrm{TL}=12.485+38.171 \mathrm{OL}$ & 25 & 0.977 & \multirow{3}{*}{$8-17$} & \multirow{3}{*}{ Present study } \\
\hline & $\mathrm{W}=9.029 \mathrm{e}^{-6} \mathrm{TL}^{3.0155}$ & 24 & 0.990 & & \\
\hline & $\mathrm{W}=0.0846 \mathrm{OL}^{2.8687}$ & 15 & 0.954 & & \\
\hline \multirow{3}{*}{ Macrodon ancylodon } & $\mathrm{TL}=-69.177+28.267 \mathrm{OL}$ & 15 & 0.980 & \multirow{3}{*}{$11-30$} & \multirow{3}{*}{ Present study } \\
\hline & $\mathrm{W}=11.444 \mathrm{e}^{-6} \mathrm{TL}^{3.3038}$ & 10 & 0.991 & & \\
\hline & $\mathrm{W}=0.0005 \mathrm{OL}^{5.1370}$ & 6 & 0.980 & & \\
\hline \multirow{3}{*}{ Paralonchurus brasiliensis } & $\mathrm{TL}=-24.228+25.294 \mathrm{OL}$ & 29 & 0.968 & \multirow{3}{*}{$10-20$} & \multirow{3}{*}{ Present study } \\
\hline & $\mathrm{W}=3.713 \mathrm{e}^{-8} \mathrm{TL}^{4.0426}$ & 29 & 0.978 & & \\
\hline & $\mathrm{W}=0.3018 \mathrm{OL}^{1.8704}$ & 34 & 0.967 & & \\
\hline \multirow{3}{*}{ Urophycis brasiliensis } & $\mathrm{TL}=-97.681+36.94 \mathrm{OL}$ & 5 & 0.978 & \multirow{3}{*}{$10-38$} & \multirow{3}{*}{ Present study } \\
\hline & $\mathrm{W}=1.6434 \mathrm{TL}^{2.8736}$ & 7 & 0.971 & & \\
\hline & $\mathrm{W}=1.4841 \mathrm{OL}^{7.8950}$ & 7 & 0.879 & & \\
\hline \multirow{3}{*}{ Mugil platanus } & $\mathrm{TL}=17.072+23.872 \mathrm{OL}$ & 44 & 0.994 & \multirow{3}{*}{$4-7$} & \multirow{3}{*}{ Present study } \\
\hline & $\mathrm{W}=2.885 \mathrm{e}^{-6} \mathrm{TL}^{3.3346}$ & 21 & 0.989 & & \\
\hline & $\mathrm{W}=0.3018 \mathrm{OL}^{2.2465}$ & 19 & 0.968 & & \\
\hline \multirow{2}{*}{ Engraulis anchoita } & $\mathrm{TL}=2.36817+3.56 \mathrm{OL}$ & 79 & 0.70 & \multirow{2}{*}{--} & \multirow{2}{*}{ Koen Alonso et al., 1998} \\
\hline & $\mathrm{W}=0.0025 \mathrm{TL}^{3.353}$ & 81 & 0.93 & & \\
\hline \multirow{2}{*}{ Stromateus brasiliensis } & $\mathrm{TL}=3.042 \mathrm{OL}^{1.159}$ & 51 & 0.98 & \multirow{2}{*}{--} & \multirow{2}{*}{ Koen Alonso et al., 1998} \\
\hline & $\mathrm{W}=0.0006418 \mathrm{TL}^{3.917}$ & 63 & 0.98 & & \\
\hline \multirow{4}{*}{ Loligo sanpaulensis } & $\mathrm{ML}=-0.330613+57.4299 \mathrm{URL}$ & 394 & 0.859 & \multirow{4}{*}{$2-19$} & \multirow{4}{*}{ Pineda et al., 1996} \\
\hline & $M L=-9.31512+63.6316 L R L$ & 414 & 0.885 & & \\
\hline & $\mathrm{LnW}=2.04038+\left(2.4808^{*} \ln U R L\right)$ & 359 & 0.879 & & \\
\hline & $\mathrm{LnW}=1.88113+(2.8300 * \operatorname{lnLRL})$ & 371 & 0.904 & & \\
\hline
\end{tabular}
41 franciscanas incidentally captured in the area. The Maximum Blubber Thickness and the Maximum Body

Table 2. Otolith-length, length-weight and otolith-weight regression used in the present study to calculate prey biomass.

References: (TL) Total length (mm); (OL) Otolith length (mm); (W) Weight (g); (ML) Mantle Length (mm), (URL) Upper Rostral Length (mm); (LRL) Lower Rostral Length (mm). 
Circumference were measured from a group of calves, in order to assess the evolution of these parameters during the lactation period.

Association patterns between prey frequency, sex, habitat and time period were verified by hierarchical log-linear analysis (Agresti, 1990). Time periods were set as two 4year segments (1993-96 and 1997-2000), whereas marine and estuarine were considered as two distinct habitats. To prevent biases from franciscanas of unknown sex, only stomach contents from 51 solid diet dolphins with confirmed sex were included in this analysis. Five prey species with IRI higher than $2 \%$ and/ or Frequencies of Occurrence above $20 \%$ were selected and, due to their estenohaline nature, the absolute frequency of cephalopods in estuarine areas were considered as structural zeros in the models. The statistical significance of the goodness-of-fit of the different log-linear models was computed by the maximum likelihood ratio Chi-square statistic.

Normality and homoscedasticity were tested by ShapiroWilk's W and Levene tests and, in the case of body condition indices, the arcsine of the square root of these proportions were used to fulfil the statistical assumptions (Zar, 1984).

\section{Results}

\section{Size range of the franciscanas studied}

The size of the franciscanas studied ranged from 56.8 to $169.5 \mathrm{~cm}$, although $95 \%$ of the dolphins were less than $140 \mathrm{~cm}$ (Figure 2). No differences in length were detected between sexes (Males: Mean=103.5cm; $S D=24.52 ; n=73$; Females: Mean=106.6cm; $S D=25.52 ; n=46 ; t=-0.66$; $\mathrm{df}=117 ; \mathrm{p}=0.51$ ) or between franciscanas belonging to estuarine or marine areas (Estuarine: Mean $=113.6 \mathrm{~cm}$; $\mathrm{SD}=18.00 ; \mathrm{n}=43$; Marine: Mean=103.1cm; $\mathrm{SD}=28.70 ; \mathrm{n}=69$; Mann-Whitney $U=1170.5 ; \mathrm{p}=0.06$ ). Incidentally captured franciscanas were significantly larger than those found stranded (Incidentally captured: Mean $=113.7 \mathrm{~cm}$;
$\mathrm{SD}=16.80 ; \mathrm{n}=80$; Stranded: Mean= 82.8cm; $\mathrm{SD}=26.29$; $\mathrm{n}=32$; Mann-Whitney $\mathrm{U}=378.5 ; \mathrm{p}<0.01$ ).

Suckling calves ranged from 56.8 to $76.5 \mathrm{~cm}$, with a weight range of $2.9-8.7 \mathrm{~kg}$. Neonates were less than $69 \mathrm{~cm}$ long (Mean=64.5cm; SD=4.38; $\mathrm{n}=15$ ) and weighed less than 3.8 $\mathrm{kg}($ Mean=3.5kg; $\mathrm{SD}=0.67 ; \mathrm{n}=14)$; non-neonates ranged from 72.3 to $76.5 \mathrm{~cm}$ in length (Mean $=74.5 \mathrm{~cm} ; \mathrm{SD}=1.42 ; \mathrm{n}=7)$ and 4.0 to $8.7 \mathrm{~kg}$ in weight (Mean=5.5kg; $\mathrm{SD}=1.85 ; \mathrm{n}=7$ ), with no overlap between both subcategories.

Transition calves ranged from 78 to $94 \mathrm{~cm}($ Mean $=86.4 \mathrm{~cm}$; $\mathrm{SD}=5.6 ; \mathrm{n}=14$ ) and 8.3 to $11.5 \mathrm{~kg}$ (Mean=9.8kg; $\mathrm{SD}=1.1 ; \mathrm{n}=9$ ). Weaned calves were longer than $97 \mathrm{~cm}$ (Mean $=102.5 \mathrm{~cm}$; $\mathrm{SD}=2.50 ; \mathrm{n}=12$ ) and weighed $13-17 \mathrm{~kg}$ (Mean=14.7kg; $\mathrm{SD}=0.80 ; \mathrm{n}=9$ ). Juveniles and adults ranged from 105.2 to $169.5 \mathrm{~cm}$ (Mean=120.5cm; SD=12.73; $=76$ ) and 17 to $36.5 \mathrm{~kg}$ $($ Mean=21.1kg; SD=5.47; $\mathrm{n}=33$ ).

\section{Body Condition and Weight}

The length-weight relationship for incidental captured franciscanas was estimated as: Body weight $(\mathrm{kg})=0.0005$ Body Length $(\mathrm{cm})^{2.2222}\left(\mathrm{r}^{2}=0.9256 ; \mathrm{SD}=2.4611 ; \mathrm{n}=41\right.$; Figure 3).

The overall fat content (Fat Index) of the franciscanas studied oscillated between 23.4 and 49.2\% (Mean=34.6\%; $\mathrm{SD}=6.92 \%$; $\mathrm{n}=27$; Table 3). No differences were found between origin, sex, habitat or feeding regime (Multifactor ANOVA $\mathrm{F}=2.9472 ; \mathrm{df}=9,10 ; \mathrm{p}=0.0537)$, but if only the feeding habits is considered as a factor, the sharp decrease of the Fat Index after weaning resulted in highly significant differences between suckling, transition and weaned franciscanas (ANOVA F=7.7052; $\mathrm{df}=2,24 ; \mathrm{p}<0.01$ ).

The Relative Index of Body Condition $(\mathrm{Kn})$ varied from 0.61 to 1.39 (Mean=0.97; $\mathrm{SD}=0.18 ; \mathrm{n}=73$ ), with highly significant differences found between categories (Multifactor ANOVA F=5.4269; $\mathrm{df}=13,45 ; \mathrm{p}<0.01$ ). Posthoc comparisons indicated that the main differences were due to the highly significant lower values of $\mathrm{Kn}$ found in stranded suckling calves versus the high values found in incidentally captured suckling and weaned

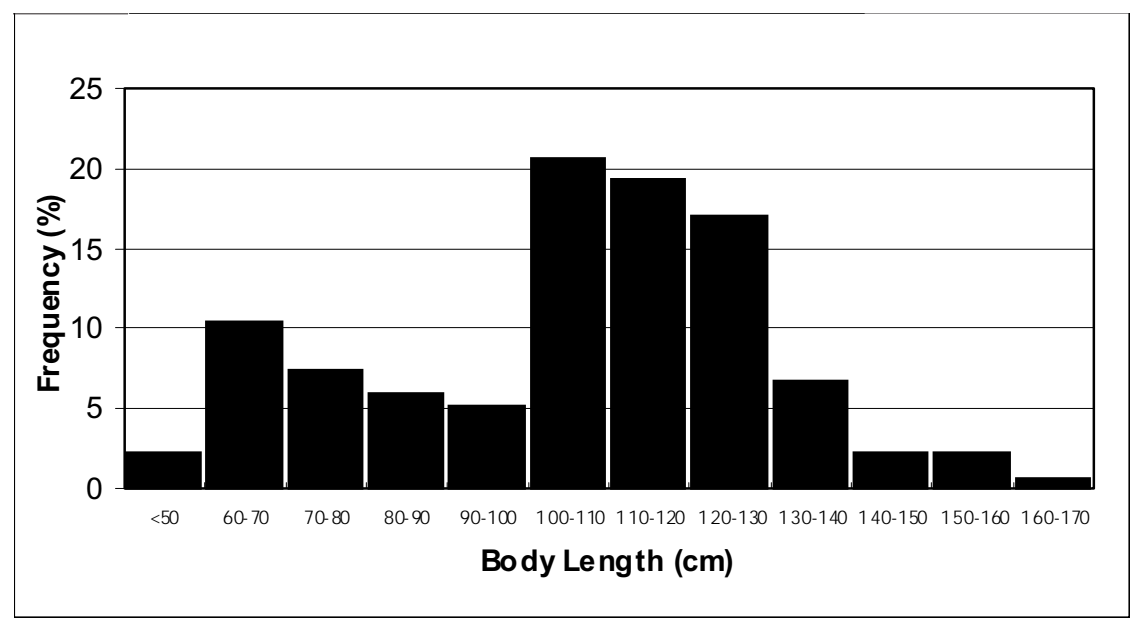

Figure 2. Length frequency distribution of the franciscanas studied. 


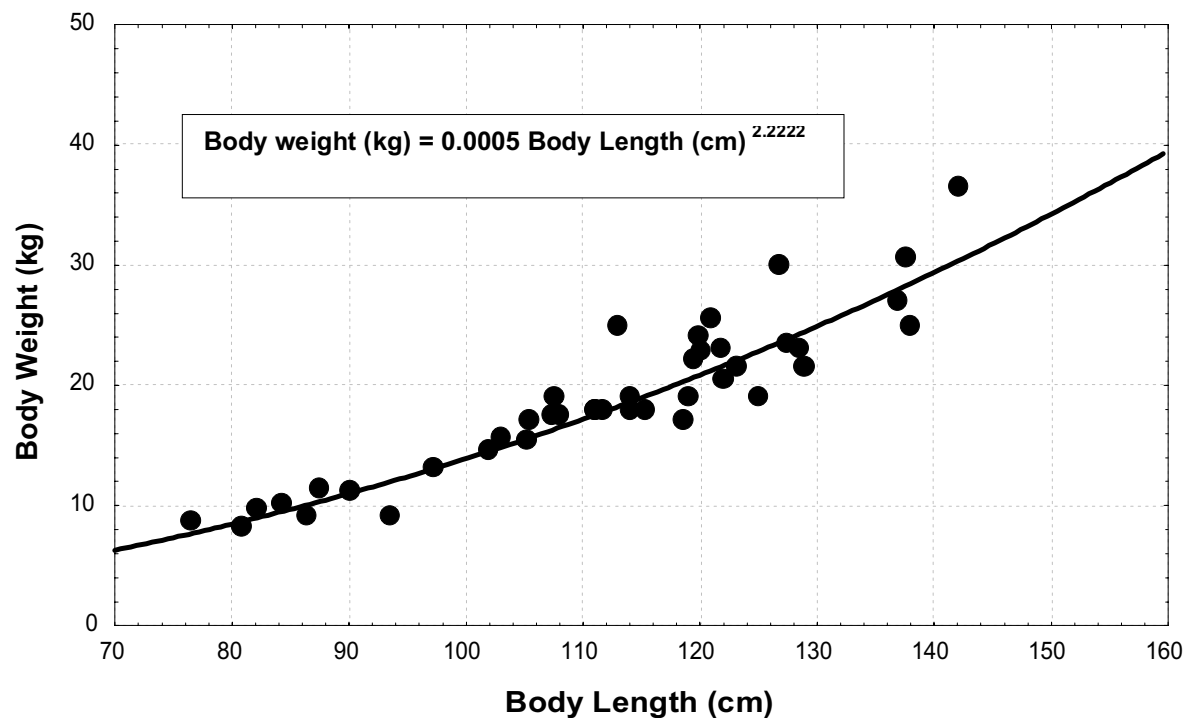

Figure 3. Length-weight relationship in incidentally captured franciscanas from Argentina.

Table 3. Indexes of Body Condition in franciscanas from northern Argentina, expressed as mean \pm standard deviation $(\mathrm{n}=)$.

\begin{tabular}{lccc}
\hline \hline Category & Fat Index (\%) & Liver Index (\%) & Body Condition Index (Kn) \\
\hline \hline Incidentally Captured & $37.1 \pm 5.87(10)$ & $2.62 \pm 0.52(14)$ & $1.028 \pm 0.120(41)$ \\
Stranded & $33.1 \pm 7.26(17)$ & $2.34 \pm 0.53(26)$ & $0.732 \pm 0.174(26)$ \\
Males & $35.5 \pm 7.48(19)$ & $2.31 \pm 0.43(28)$ & $0.915 \pm 0.198(48)$ \\
Females & $32.4 \pm 5.18(8)$ & $2.78 \pm 0.65(13)$ & $0.908 \pm 0.214(25)$ \\
Marine & $36.0 \pm 7.80(13)$ & $2.61 \pm 0.59(19)$ & $0.848 \pm 0.219(39)$ \\
Estuarine & $30.2 \pm 6.33(7)$ & $2.35 \pm 0.58(15)$ & $0.999 \pm 0.155(24)$ \\
Suckling Calves & $40.7 \pm 4.97(6)$ & $2.51 \pm 0.57(10)$ & $0.682 \pm 0.143(21)$ \\
Transition Calves & $39.1 \pm 8.03(4)$ & $2.20 \pm 0.16(4)$ & $0.995 \pm 0.122(9)$ \\
Weaned Calves, Juveniles and Adults & $31.3 \pm 5.24(17)$ & $2.41 \pm 0.56(26)$ & $1.021 \pm 0.119(41)$ \\
\hline \hline
\end{tabular}

franciscanas. When independent analyses were performed within stranded and incidentally killed franciscanas, no significant differences between areas, sexes and feeding categories were found (Stranded $\mathrm{F}=2.4091 ; \mathrm{df}=4,18 ; \mathrm{p}=0.087$; incidentally killed $\mathrm{F}=1.2732$; $\mathrm{df}=8,27 ; \mathrm{p}=0.298$ ).

The relative weight of liver (Liver Index) fluctuated between 1.5 and $4 \%($ Mean $=2.5 \%$; $S D=0.55 \% ; n=41)$, also with significant differences between categories (Multifactor ANOVA F=2.3274; $\mathrm{df}=9,23 ; \mathrm{p}=0.0494$ ) due to higher values found in females.

Significant differences in the maximum body circunsference and blubber thickness were found between suckling, transition and weaned calves (Table 4).

Table 4. Variation in the Maximum Blubber Thickness $(\mathrm{cm})$ and Maximum Body Circumference $(\mathrm{cm})$ during the first year of life in franciscanas from Argentina. Values expressed as mean \pm standard deviation $(n=)$; differences analysed by one-factor ANOVA.

\begin{tabular}{lcccc}
\hline \hline Characteristic & Suckling Calves & Transition Calves & Weaned Calves & Differences \\
\hline \hline Maximum Blubber Thickness & $1.53 \pm 0.47(13)$ & $2.75 \pm 0.35(2)$ & $2.53 \pm 0.38(4)$ & $* *(\mathrm{~F}=12.15 ; \mathrm{df}=2,16 ; \mathrm{p}<0.01)$ \\
Maximum Body Circumference & $37.52 \pm 5.85(17)$ & $56.20 \pm 2.63(5)$ & $62.78 \pm 1.86(5)$ & $* * \quad(\mathrm{~F}=64.11 ; \mathrm{df}=2,24 ; \mathrm{p}<0.01)$ \\
\hline \hline
\end{tabular}


Lactation chronology and transition to solid feeding

Suckling calves were found from early October to early February, although they were more frequently found from November onwards (Figure 4). Mean record date was 12 December ( \pm 34 days), ranging from 2 October to 7 February. Transition calves were recorded from December onwards, being more common in February (Figure 4); mean record date was 4 February ( \pm 26 days), with a period extending from 18 December to 15 April, after which no franciscanas with traces of milk were recorded.

\section{Diet Composition}

In franciscanas from the northern coast of Argentina, we identified as prey a total of 20 teleosts, 2 cephalopods and 4 crustacean species (Appendix I). The number of prey species increased with dolphin age, with juveniles and adults typically preying upon twice as many species as transition and weaned calves (Figure 5).

Forty-four percent of the franciscana calves analysed presented only milk in their stomachs, whereas $28 \%$ had a transition diet (milk plus solid food) and the rest (28\%) had exclusively solid prey remains. No juveniles with milk traces were found.

Crustaceans were the most frequent and abundant prey in transition calves, followed by fish and cephalopods (Table 5). For post-weaning franciscanas, fish become the most frequent and abundant group, and cephalopods also become more important. The diet of juveniles and adults was also composed primarily of fish, whereas cephalopods and crustaceans increase in importance. The teleost family Sciaenidae was found to be the predominant prey.

In both transition and weaned franciscana calves the striped weakfish, Cynoscion guatucupa and the white croaker,

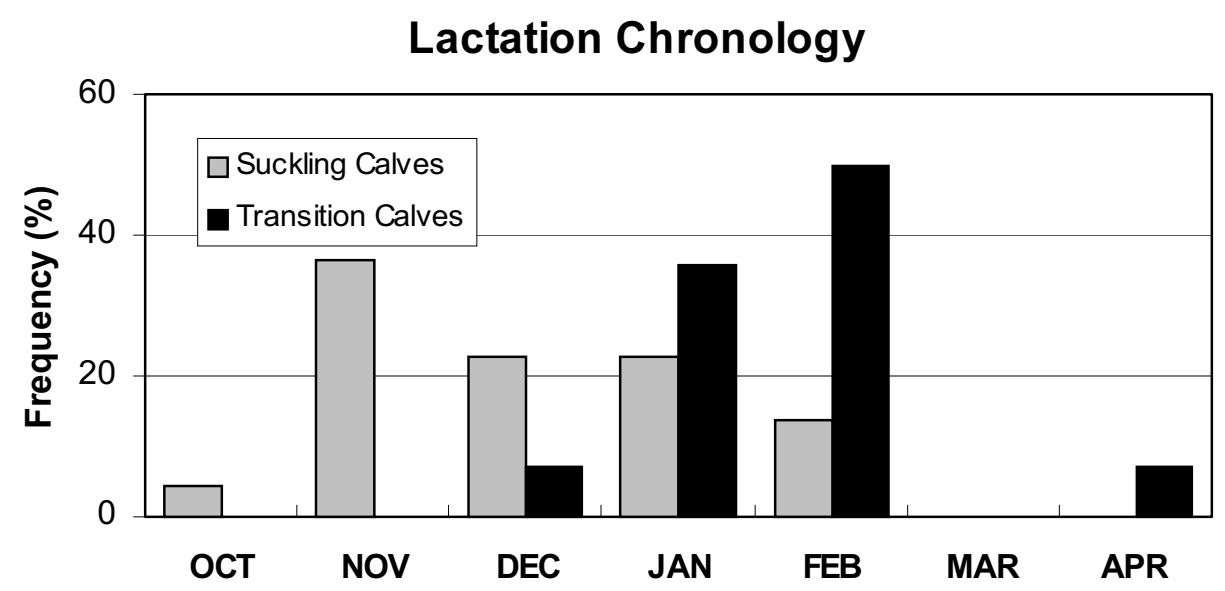

Figure 4. Monthly records of suckling and transition franciscana calves.

\section{Diet Composition}

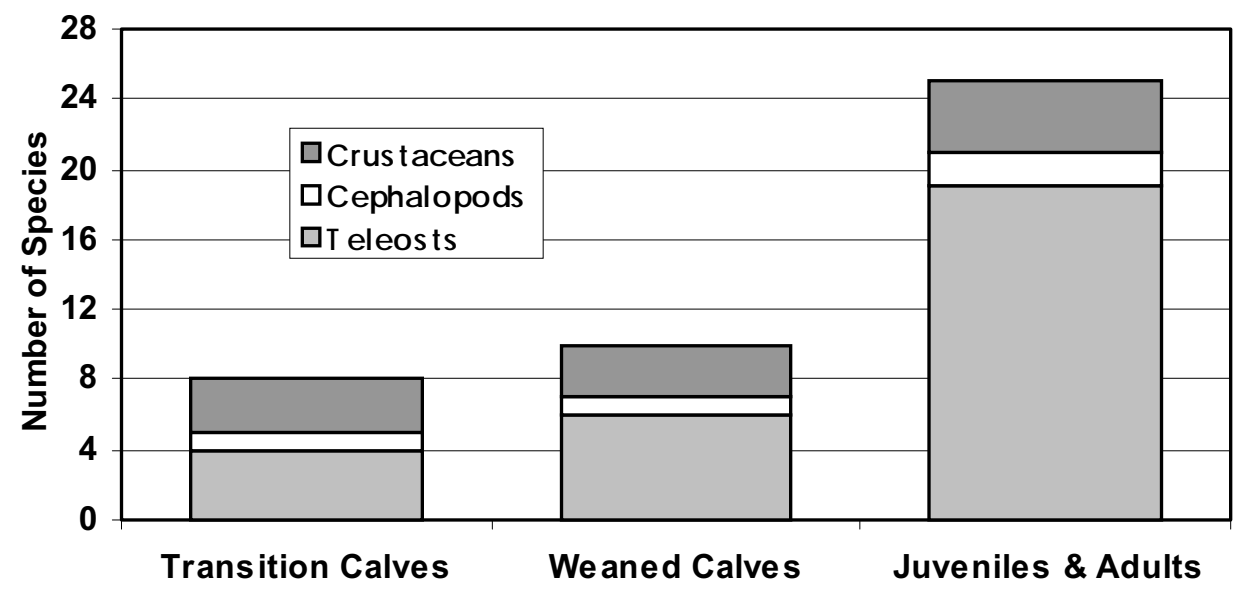

Figure 5. Number of prey species taken by franciscanas of different ontogenic categories. 
Table 5. Absolute number $(\mathrm{n}=)$, numerical abundance $(\mathrm{N} \%)$, frequency of occurrence (FO\%), biomass (W\%), absolute (IRI) and percentage Index of Relative Importance (IRI\%) of prey of franciscanas from northern Argentina.

\begin{tabular}{|c|c|c|c|c|c|c|c|c|c|c|c|c|}
\hline \multirow[t]{2}{*}{ PREY ITEMS } & \multicolumn{3}{|c|}{$\begin{array}{l}\text { 'TRANSITION' CALVES } \\
(\mathrm{n}=14)\end{array}$} & \multicolumn{3}{|c|}{$\begin{array}{l}\text { WEANED CALVES } \\
(\mathrm{n}=14)\end{array}$} & \multicolumn{6}{|c|}{ POOLED JUVENILES \& ADULTS $(n=60)$} \\
\hline & $\mathrm{n}=$ & $\mathrm{N} \%$ & $\mathrm{FO} \%$ & $\mathrm{n}=$ & $\mathrm{N} \%$ & $\mathrm{FO} \%$ & $\mathrm{n}=$ & $\mathrm{N} \%$ & $\mathrm{FO} \%$ & $\mathrm{~W} \%$ & IRI & IRI $\%$ \\
\hline TELEOSTS & 36 & 10.4 & 71.4 & 263 & 90.4 & 100.0 & 2844 & 80.5 & 96.9 & 72.0 & 14780.3 & 92.2 \\
\hline Micropogonias furnieri & 2 & 0.6 & 25.0 & 133 & 45.7 & 50.0 & 500 & 14.1 & 40.9 & 24.3 & 1574.3 & 20.4 \\
\hline Cynoscion guatucupa & 29 & 8.4 & 50.0 & 69 & 23.7 & 83.3 & 1637 & 46.3 & 60.6 & 23.8 & 4250.8 & 55.2 \\
\hline Odonthestes argentinensis & & & & 37 & 12.7 & 16.7 & 198 & 5.6 & 13.6 & 6.7 & 167.5 & 2.2 \\
\hline Macrodon ancylodon & & & & & & & 17 & 0.5 & 10.6 & 6.7 & 76.7 & 1.0 \\
\hline Paralonchurus brasiliensis & 4 & 1.2 & 12.5 & 16 & 5.5 & 33.3 & 127 & 3.6 & 19.7 & 2.3 & 116.9 & 1.5 \\
\hline Urophycis brasiliensis & & & & 3 & 1.0 & 33.3 & 116 & 3.3 & 24.2 & 7.4 & 258.9 & 3.4 \\
\hline Mugil platana & & & & & & & 9 & 0.3 & 7.6 & 0.1 & 2.5 & 0.0 \\
\hline Engraulis anchoita & & & & 5 & 1.7 & 33.3 & 28 & 0.8 & 24.2 & 0.4 & 29.8 & 0.4 \\
\hline Stromateus brasiliensis & & & & & & & 7 & 0.2 & 3.0 & 0.2 & 1.1 & 0.0 \\
\hline Umbrina canosai & & & & & & & 125 & 3.5 & 15.2 & & & \\
\hline Lycengraulis olidus & & & & & & & 4 & 0.1 & 4.5 & & & \\
\hline Pomatomus saltatrix & & & & & & & 2 & 0.1 & 3.0 & & & \\
\hline Ramnogaster arcuata & & & & & & & 9 & 0.3 & 3.0 & & & \\
\hline Percophis brasiliensis & & & & & & & 1 & 0.1 & 1.5 & & & \\
\hline Sparus pagrus & & & & & & & 11 & 0.3 & 7.6 & & & \\
\hline Trachurus lathami & & & & & & & 49 & 1.4 & 1.5 & & & \\
\hline Pogonias cromis & & & & & & & 2 & 0.1 & 1.5 & & & \\
\hline Raneya fluminensis & & & & & & & 1 & 0.1 & 1.5 & & & \\
\hline Anchoa marini & & & & & & & 1 & 0.1 & 1.5 & & & \\
\hline Leptonotus blanvillanus & 1 & 1.0 & & & & & & & & & & \\
\hline CEPHALOPODS & 1 & 0.3 & 12.5 & 16 & 5.5 & 16.7 & 443 & 12.5 & 30.8 & 28.0 & 1248.3 & 7.8 \\
\hline Loligo sanpaulensis & 1 & 0.3 & 12.5 & 16 & 5.5 & 16.7 & 441 & 12.5 & 30.3 & 28.0 & 1227.5 & 15.9 \\
\hline Octopus tehuelchus & & & & & & & 2 & 0.1 & 1.5 & & & \\
\hline CRUSTACEANS & 181 & 52.5 & 85.7 & 9 & 3.1 & 50.0 & 238 & 6.7 & 49.2 & & & \\
\hline Artemesia longinaris & 3 & 0.9 & 12.5 & 1 & 0.3 & 16.7 & 197 & 5.6 & 28.8 & & & \\
\hline Peisos petrunkievitchi & 9 & 2.6 & 12.5 & 7 & 2.4 & 33.3 & 24 & 0.7 & 15.2 & & & \\
\hline Peneidae & 4 & 1.2 & 25.0 & 1 & 0.3 & 16.7 & 7 & 0.2 & 10.6 & & & \\
\hline Neomysis americana & 135 & 39.1 & 25.0 & & & & 6 & 0.2 & 1.5 & & & \\
\hline Pleoticus muelleri & & & & & & & 4 & 0.1 & 1.5 & & & \\
\hline Calanoid Copepods & 30 & 8.7 & 25.0 & & & & & & & & & \\
\hline OTHERS & 128 & 37.1 & 25.0 & 3 & & & 8 & & & & & \\
\hline Nereid Polychaetes & 128 & 37.1 & 25.0 & 3 & 1.0 & 50.0 & 8 & 0.2 & 10.6 & & & \\
\hline TOTAL & 346 & & & 291 & & & 3533 & & & & & \\
\hline
\end{tabular}

continued... 
Table 5. Absolute number $(\mathrm{n}=)$, numerical abundance $(\mathrm{N} \%)$, frequency of occurrence (FO\%), biomass (W\%), absolute (IRI) and percentage Index of Relative Importance (IRI\%) of prey of franciscanas from northern Argentina.

...continued

\begin{tabular}{|c|c|c|c|c|c|c|c|c|c|c|c|c|}
\hline \multirow{2}{*}{ PREY ITEMS } & \multicolumn{6}{|c|}{ MARINE JUVENILES \& ADULTS (n=27) } & \multicolumn{6}{|c|}{ ESTUARINE JUVENILES \& ADULTS (n=33) } \\
\hline & $\mathrm{n}=$ & $\mathrm{N} \%$ & $\mathrm{FO} \%$ & $\mathrm{~W} \%$ & IRI & IRI\% & $\mathrm{n}=$ & $\mathrm{N} \%$ & $\mathrm{FO} \%$ & $\mathrm{~W} \%$ & IRI & IRI\% \\
\hline TELEOSTS & 1520 & 71.3 & 96.7 & 51.2 & 11844.8 & 71.9 & 1324 & 94.4 & 97.1 & 100.0 & 18876.2 & 100.0 \\
\hline Micropogonias furnieri & 44 & 2.1 & 16.1 & 1.3 & 54.6 & 0.4 & 456 & 32.5 & 62.9 & 55.4 & 5526.4 & 66.8 \\
\hline Cynoscion guatucupa & 1208 & 56.7 & 83.9 & 36.3 & 7798.0 & 60.7 & 429 & 30.6 & 40.0 & 7.0 & 1503.2 & 18.2 \\
\hline $\begin{array}{l}\text { Odonthestes } \\
\text { argentinensis }\end{array}$ & 39 & 1.8 & 3.2 & 0.8 & 8.5 & 0.1 & 159 & 11.3 & 22.9 & 14.6 & 593.0 & 7.2 \\
\hline Macrodon ancylodon & & 0.0 & 3.2 & 0.0 & 0.0 & 0.0 & 17 & 1.2 & 17.1 & 15.8 & 291.1 & 3.5 \\
\hline $\begin{array}{l}\text { Paralonchurus } \\
\text { brasiliensis }\end{array}$ & 52 & 2.4 & 16.1 & 1.2 & 58.7 & 0.5 & 75 & 5.3 & 22.9 & 3.9 & 210.8 & 2.5 \\
\hline Urophycis brasiliensis & 73 & 3.4 & 25.8 & 10.8 & 368.3 & 2.9 & 43 & 3.1 & 22.9 & 2.7 & 132.9 & 1.6 \\
\hline Mugil platana & 2 & 0.1 & 6.5 & 0.1 & 1.3 & 0.0 & 7 & 0.5 & 8.6 & 0.1 & 5.5 & 0.1 \\
\hline Engraulis anchoita & 24 & 1.1 & 38.7 & 0.6 & 68.3 & 0.5 & 4 & 0.3 & 11.4 & 0.2 & 5.1 & 0.1 \\
\hline Stromateus brasiliensis & 4 & 0.2 & 3.2 & 0.1 & 0.8 & 0.0 & 3 & 0.2 & 2.9 & 0.3 & 1.5 & 0.0 \\
\hline Umbrina canosai & 7 & 0.3 & 6.5 & & & & 118 & 8.4 & 22.9 & & & \\
\hline Lycengraulis olidus & 3 & 0.1 & 6.5 & & & & 1 & 0.1 & 2.9 & & & \\
\hline Pomatomus saltatrix & 1 & 0.0 & 3.2 & & & & 1 & 0.1 & 2.9 & & & \\
\hline Ramnogaster arcuata & 1 & 0.0 & 3.2 & & & & 8 & 0.6 & 2.9 & & & \\
\hline Percophis brasiliensis & 1 & 0.0 & 3.2 & & & & & & & & & \\
\hline Sparus pagrus & 10 & 0.5 & 12.9 & & & & 1 & 0.1 & 2.9 & & & \\
\hline Trachurus lathami & 49 & 2.3 & 3.2 & & & & & & & & & \\
\hline Pogonias cromis & & & & & & & 2 & 0.1 & 2.9 & & & \\
\hline Raneya fluminensis & 1 & 0.0 & 3.2 & & & & & & & & & \\
\hline Anchoa marini & 1 & 0.0 & 3.2 & & & & & & & & & \\
\hline Leptonotus blanvillanus & & & & & & & & & & & & \\
\hline CEPHALOPODS & 443 & 20.8 & 66.7 & 48.8 & 4639.5 & 28.1 & 0 & 0.0 & 0.0 & 0.0 & & \\
\hline Loligo sanpaulensis & 441 & 20.7 & 64.5 & 48.8 & 4483.4 & 34.9 & & & & & & \\
\hline Octopus tehuelchus & 2 & 0.1 & 3.2 & & & & & & & & & \\
\hline CRUSTACEANS & 165 & 7.7 & 43.3 & & & & 73 & 5.2 & 57.1 & & & \\
\hline Artemesia longinaris & 147 & 6.9 & 32.3 & & & & 50 & 3.6 & 25.7 & & & \\
\hline Peisos petrunkievitchi & 10 & 0.5 & 6.5 & & & & 14 & 1.0 & 22.9 & & & \\
\hline Peneidae & 4 & 0.2 & 12.9 & & & & 3 & 0.2 & 8.6 & & & \\
\hline Neomysis americana & & & & & & & 6 & 0.4 & 2.9 & & & \\
\hline Pleoticus muelleri & 4 & 0.2 & 3.2 & & & & & & & & & \\
\hline Calanoid Copepods & & & & & & & & & & & & \\
\hline OTHERS & 3 & 0.1 & & & & & 5 & & & & & \\
\hline Nereid Polychaetes & 3 & 0.1 & 9.7 & & & & 5 & 0.4 & 11.4 & & & \\
\hline TOTAL & 2131 & & & & & & 1402 & & & & & \\
\hline
\end{tabular}


Micropogonias furnieri, were the prey most frequently found, followed by the longfin inshore squid, Loligo sanpaulensis, the Argentine stiletto shrimp, Artemesia longinaris and the shrimp, Peisos petrunkevitchi. By contrast, the mysid Neomysis americana was frequently found in transition calves, but was virtually absent after weaning.

The main prey species (FO\% and N\%) for juveniles and adults were C. guatucupa, M. furnieri, L. sanpaulensis, A. longinaris and the silverside, Odonthestes argentinensis, constituting more than $80 \%$ of the prey ingested and the diet biomass (Table 5). The Brazilian codling, Urophycis brasiliensis and king weakfish, Macrodon ancylodon complemented this group, comprising about $14 \%$ of the diet biomass. The Index of Relative Importance confirms the above findings as M. furnieri, C. guatucupa and L. sanpaulensis were the most important prey species of franciscanas from northern Argentina (IRI> 90\%; Table 5).
Prey Size

Prey size was estimated for the most important prey items in the diet of franciscanas. The range of fish size was similar for dolphins from estuarine and marine areas, with a major predation on specimens from 40 to $60 \mathrm{~mm}$ (Total Length) in the marine area, and $40-80 \mathrm{~mm}$ in estuarine areas (Figure 6). Most of the fish preyed in both areas weighed less than $5 \mathrm{~g}$ (Figure 7). Sixty percent of the cephalopods showed a mantle length of $40-80 \mathrm{~mm}$ (Figure 8 ), with $50 \%$ having values of less than $10 \mathrm{~g}$ (Figure 9).

\section{Diet Variation}

Log-linear models revealed highly significant associations between prey frequency and habitat, but no association was found with years and sexes (Table 6).

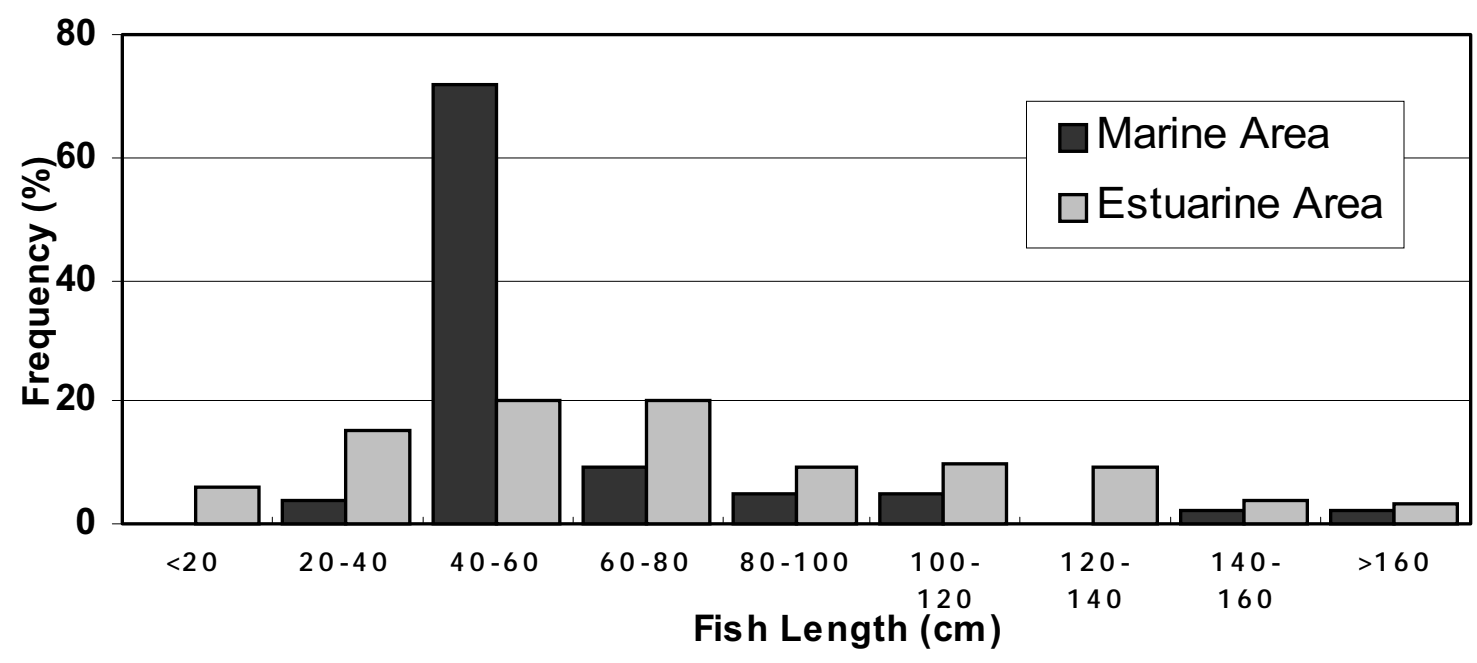

Figure 6. Length frequency distribution of fish prey eaten by franciscanas.

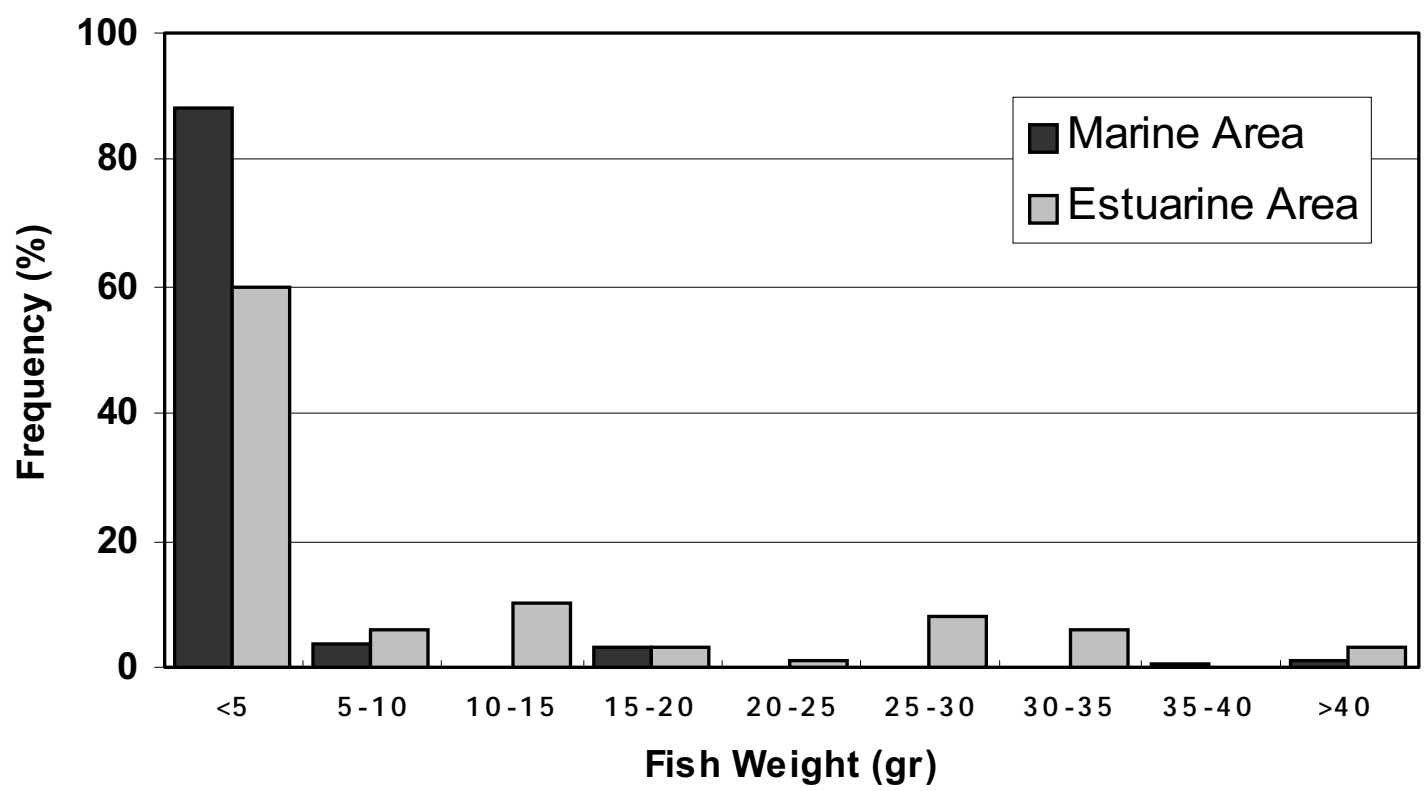

Figure 7. Weight frequency distribution of fish prey eaten by franciscanas. 


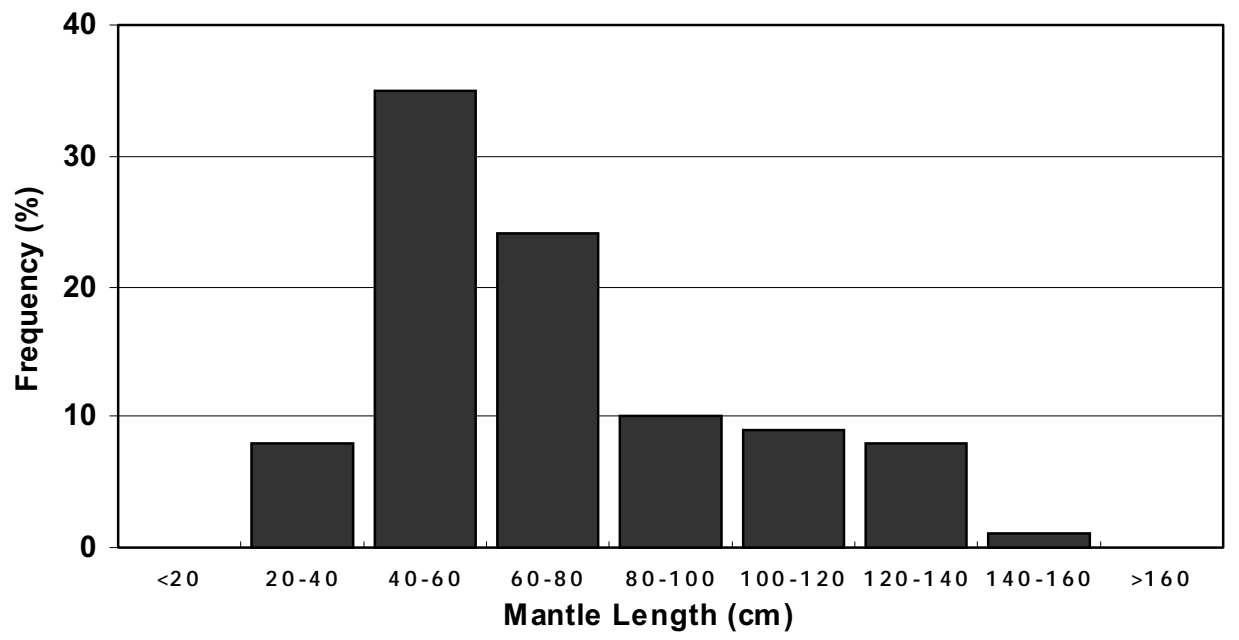

Figure 8. Mantle length frequency distribution of squid prey eaten by franciscanas.

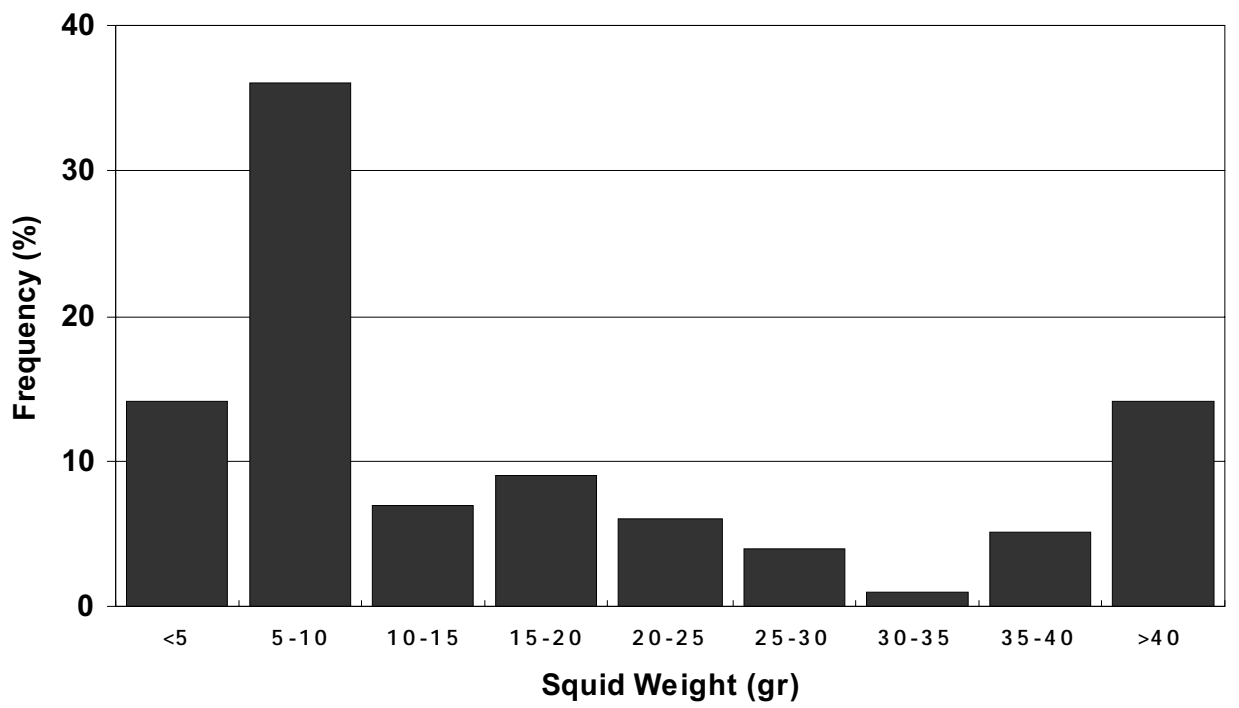

Figure 9. Weight frequency distribution of squid prey eaten by franciscanas.

Table 6. Associations (likelihood-ratio) between time period, habitat, sex and prey frequency. Statistical tests used were from a hierarchical log-linear analysis of a contingency table of time period ( 2 levels), habitat (2 levels), sex (2 levels) and prey (5 levels).

\begin{tabular}{lccc}
\hline Effect & d.f. & Chi-Square & $\mathrm{P}$ \\
\hline \hline Period x Habitat & 1 & 0.095 & 0.758 \\
Period x Sex & 1 & 1.381 & 0.240 \\
Period x Prey & 4 & 2.577 & 0.631 \\
Habitat x Sex & 1 & 1.489 & 0.222 \\
Habitat x Prey & 4 & 24.011 & $<0.001$ \\
Sex x Prey & 4 & 3.361 & 0.499 \\
Period x Habitat x Sex & 1 & 3.438 & 0.064 \\
Period x Habitat x Prey & 4 & 4.546 & 0.337 \\
Period x Sex x Prey & 4 & 2.468 & 0.650 \\
Habitat x Sex x Prey & 4 & 0.768 & 0.943 \\
\hline \hline
\end{tabular}


The most important prey species in the marine area were $C$. guatucupa, L. sanpaulensis and U. brasiliensis, accounting for $89.8 \%$ of the total (Table 5). Though the shrimp A. longinaris was likely an important prey species, it was not possible to estimate its contribution by biomass from the exoskeletons recovered. The most important feature of the estuarine area was the absence of cephalopods, due their estenohaline habits. For dolphins in the estuarine area, $M$. furnieri was clearly the most important prey, whereas O. argentinensis, M. ancylodon, the drum, Paralonchurus brasiliensis and C. guatucupa sum a total of $31.4 \%$ (Table 5). With the exception of the latter, the other species were not important in the marine area.

Of the total 24 species found in the diet of franciscanas from northern Argentina, the species richness in the marine area was slightly higher than in the estuary (23 vs 17). Although there was a lower number of prey species in estuarine waters, no significant differences were found in the mean number of prey species per stomach content between both areas (3.20 \pm 1.729 vs $3.87 \pm 1.224 ; \mathrm{t}=-1.766 ; \mathrm{p}=0.082 ; \mathrm{df}=58)$. The combination of major prey taxa found in franciscana stomachs was also different in both areas, with a higher proportion of the combinations teleosts-cephalopods or teleosts-cephalopods-crustaceans in the marine area. Estuarine dolphins mainly showed only teleosts or the combination teleosts-crustaceans as prey (Table 7).

Although not significant, there was a tendency to record $L$. sanpaulensis and Paralonchurus brasiliensis more frequently in males, A. longinaris, $U$. brasiliensis and $U$. canosai in females (Table 8). M. furnieri and C. guatucupa were equally recorded in both sexes. No differences were found between sexes when comparing the mean number of prey species per stomach, neither for fish only (ANOVA; $F=0.6311 ; \mathrm{df}=2$, $57 ; \mathrm{p}=0.5356$ ) nor for all the prey species included (ANOVA; $\mathrm{F}=0.5199 ; \mathrm{df}=2,55 ; \mathrm{p}=0.5975)$ (Table 9).

Table 7. Occurrence of different prey combinations in franciscana stomach contents from marine and estuarine habitats.

\begin{tabular}{lcc}
\hline \hline Prey Combination & Marine Habitats & Estuarine Habitats \\
\hline \hline Only Cephalopods & $3.7 \%$ & --- \\
Only Crustaceans & $3.7 \%$ & $3.0 \%$ \\
Only Fish & $7.4 \%$ & $36.4 \%$ \\
Cephalopods and Crustaceans & --- & --- \\
Cephalopods and Fish & $37.0 \%$ & --- \\
Crustaceans and Fish & $18.5 \%$ & $60.6 \%$ \\
Crustaceans, Cephalopods and Fish & $29.6 \%$ & --- \\
\hline \hline
\end{tabular}

Table 8. Sexual differences in the frequence of occurence (\%) of selected prey species.

\begin{tabular}{lcccc}
\hline \multirow{2}{*}{ Prey Species } & \multicolumn{2}{c}{ Marine } & \multicolumn{2}{c}{ Estuarine } \\
& Males & Females & Males & Females \\
\hline \hline M.furnieri & 15.4 & 16.7 & 63.2 & 69.2 \\
C.guatucupa & 76.9 & 83.3 & 52.6 & 30.8 \\
P.brasiliensis & 30.8 & 8.3 & 36.8 & 7.7 \\
U.brasiliensis & 23.1 & 41.7 & 21.1 & 30.8 \\
U. canosai & 7.7 & 8.3 & 10.5 & 46.2 \\
L.sanpaulensis & 76.9 & 50.0 & 0.0 & 0.0 \\
A. longinaris & 23.1 & 58.3 & 21.1 & 30.8 \\
\hline
\end{tabular}

Table 9. Mean number of prey species found per stomach content, expressed as mean \pm standard deviation $(\mathrm{n}=)$.

\begin{tabular}{lcccc}
\hline Prey Species & Males & Females & Undetermined & Overall \\
\hline \hline Teleosts & $2.82 \pm 1.59(28)$ & $2.43 \pm 1.42(21)$ & $2.44 \pm 1.25(9)$ & $2.62 \pm 1.44(58)$ \\
All prey items & $3.79 \pm 1.82(29)$ & $3.50 \pm 1.41(22)$ & $3.11 \pm 1.62(9)$ & $3.58 \pm 1.64(60)$ \\
\hline \hline
\end{tabular}


Estimation of the minimum number of stomach contents required for analysis

In feeding ecology studies, prey importance and richness are usually estimated without an assessment of the minimum number of samples required to support the conclusions. We retrocalculated the minimum number of samples required to properly describe the diet of franciscanas from northern Argentina, choosing randomly an increasing number of stomachs contents and estimating the cumulative frequency of the prey species found (Pierce and Boyle, 1991). In the case of prey importance, we selected only those species with IRI higher than $2 \%$.

In the present set of stomach contents, ten to fifteen franciscana stomachs were necessary to account for the majority $(\sim 80 \%)$ of the most important prey; as the diet from the marine habitat showed fewer number of important prey species ( 3 vs 5), it would require less than 10 samples (Figure 10). When we calculated the number of stomachs contents required to account for the $80 \%$ of the total number of prey species in the diet, we found that we should analyse 20-30 stomach contents (Figure 10).
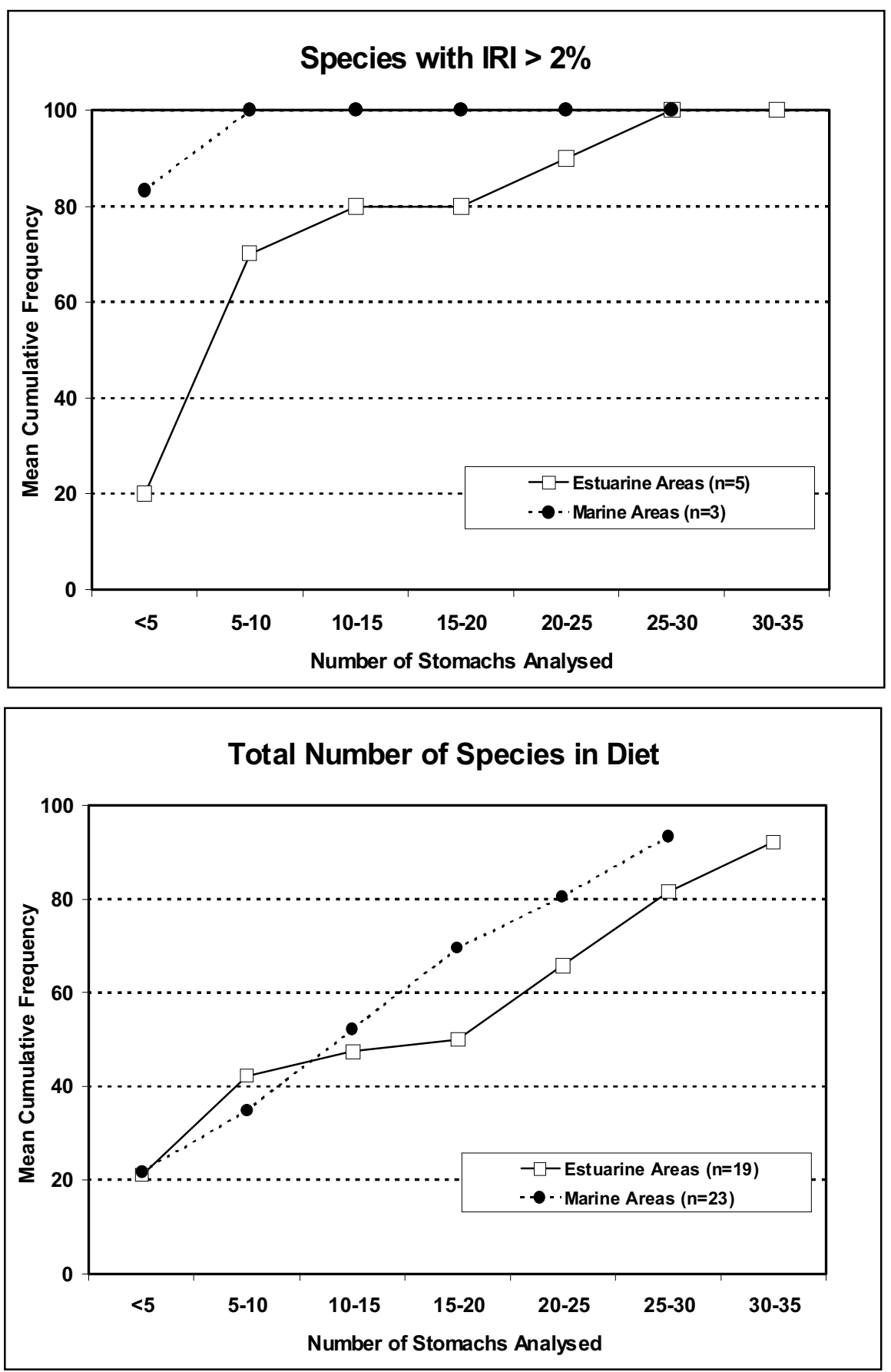

Figure 10. Estimated number of stomachs required for prey importance and richness analysis. 


\section{Discussion}

Pontoporia blainvillei is the South American cetacean with the earliest references on diet (Burmeister, 1867; Lahille, 1905; Cabrera and Yepes, 1940). During the last few decades this species has been the subject of an increasing number of feeding studies (Fitch and Brownell, 1971; Pinedo, 1982; Praderi, 1984, 1986; Perez Macri, 1987; Bastida et al., 1992; Ott, 1994, 2000; Perez et al., 1996; Bassoi, 1997; Di Beneditto et al., 1998; Oliveira et al., 1998; Bassoi et al., 2000), which have helped to establish a baseline of qualitative data throughout most of their distribution. More recently there has been a growing tendency to develop quantitative studies, which are fundamental in future studies on energetic requirements. The present paper updates the information on franciscana's diet in northern Argentina, interprets differences in feeding habits between marine and estuarine habitats and gives an insight on early stages of predation.

\section{Lactation and transition to solid diet}

The frequent live strandings of newborn calves in the northern coast of Argentina allowed us to study in detail the first year of life and the lactation period, two of the least known aspects of the life history of franciscanas. Calving season extends for approximately 4 months, from early October to February, with most occurrences in November. This period coincides with the proposed calving season in Uruguay and southern Brazil (Harrison et al., 1981; Brownell, 1984; Pinedo et al., 1989; Danilewicz and Secchi, 2000).

Considering the time elapsed between the recording dates of newborn and transition calves, we found a consistent period of 2.5 months in both the earliest (2 October vs 18 December) and latest (7 February vs 15 April) records. Thus, we estimated that the onset of solid food intake is approximately between 2 and 3 months of age, when the calves exceed $75 \mathrm{~cm}$ in length and $8 \mathrm{~kg}$ of weight. This age coincides with that suggested by Kasuya and Brownell (1979) and Brownell (1989). Di Beneditto and Ramos (2000) reported milk and solid remains in 4 calves longer than $78 \mathrm{~cm}$, coinciding with teeth eruption.

Our results confirm a gradual weaning in franciscana calves, with a suggested feeding independence when calves exceed $95 \mathrm{~cm}$ in length and $13 \mathrm{~kg}$ in weight. This could take place in April, when calves are about 7 months old. Such a lactation strategy agrees with the suggestions of Kasuya and Brownell (1979) and Pinedo and Hohn (2000), who stated that the intake of solid food early in life and the corresponding assimilation of calcium are responsible for the conspicuous boundary layers between initial GLGs found in franciscana teeth. Another clear indication of early predation by franciscanas are the detectable concentrations of mercury and cadmium transferred via fish and cephalopods, found by Gerpe et al. (2002) in franciscana calves from the same region.

The age at which franciscanas start taking solid food might help to explain why they get entangled in gillnets. An analysis of the lengths of franciscanas entangled in northern Argentina suggests that the critical period is the range 75$80 \mathrm{~cm}$, when entangled animals outnumber those of strandings, coinciding with the initial stages of predation by transition calves (Figure 11).

The diet of both transition and weaned calves was found to be less species rich than older animals. The solid diet of transition calves from both habitats was more similar to the diet of estuarine juveniles and adults, suggesting certain dependence of calves on brackish habitats during the transition to solid feeding. An important prey species during this period was the mysid N. americana, which is very abundant in Bahía Samborombón and also a major constituent of other species' diet in the Rio de la Plata estuary, such as M. furnieri ( $\mathrm{FO} \%=55 \%$, Sánchez et al., 1991) and M. ancylodon $(\mathrm{FO} \%=88.8 \%$, Leta, 1987). The Argentine

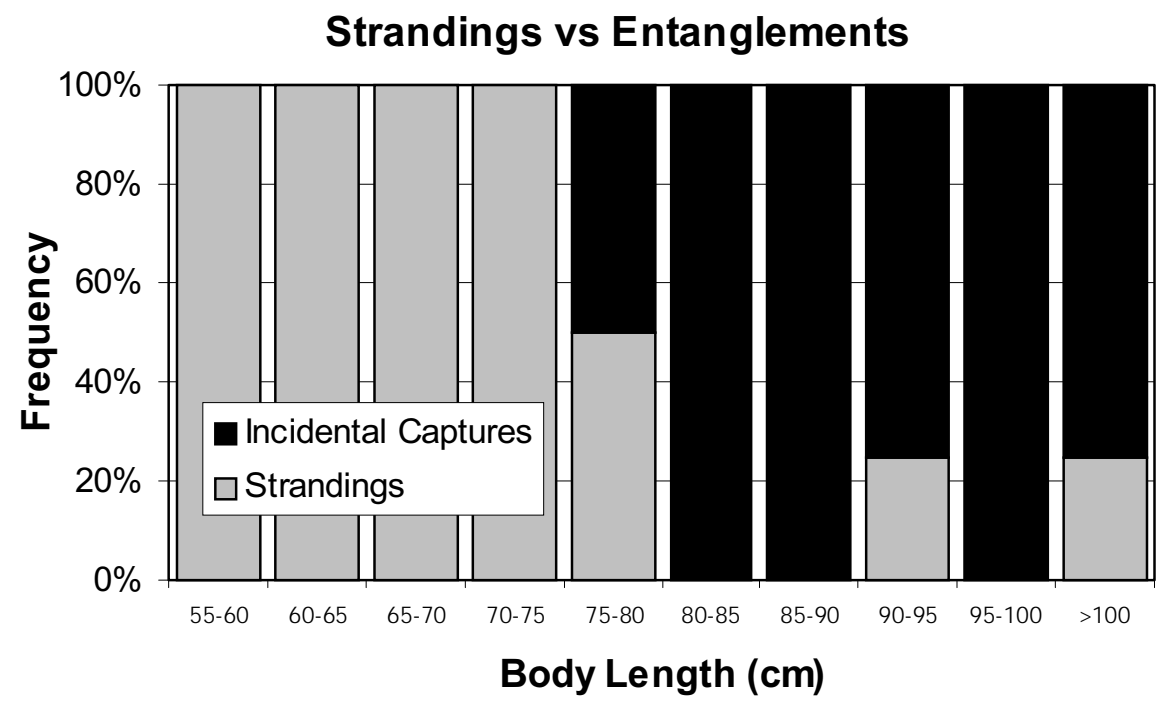

Figure 11. Proportion of incidental catches and strandings of franciscana calves, discriminated by body length (cm). 
red shrimp, Pleoticus muelleri, and A. longinaris are also frequently eaten by juvenile franciscanas in southern Brazil (Bassoi, 1997; Bassoi et al., 2000) and a high incidence of euphausiids characterise the transition diet of harbour porpoises from the Gulf of Maine (Smith and Read, 1982; Gannon et al., 1998). Smith and Read (1992) suggested that these calves eat crustaceans while mothers are feeding on euphausiid predators, a strategy that is likely to occur with Pontoporia and Neomysis.

In contrast, the prey species composition of post-weaning calves from both habitats resembles that of juvenile and adult franciscanas from marine habitats. Moreover, all prey species eaten by weaned calves were present in marine diets. Complementary foraging in estuarine areas should not be excluded, due to the important presence of $M$. furnieri.

In newborn franciscanas, blubber represented approximately $40 \%$ of the body weight, a percentage that decreases with trophic independence. Kamiya and Yamasaki (1974) recorded an overall mean of $30.1 \%$, with a decrease between young (35.8\%) and adults (25.5\%). Caon and Fialho (1999) also reported decreasing fat contents from calves $(33.9 \%)$ to juveniles $(29.7 \%)$ and adults $(24.3 \%)$ in dolphins from southern Brazil. Blubber thickness and body circumference showed a clear increase after predation, suggesting an important growth in weight during the early months of life in Pontoporia. Blubber thickness coincided with the $1.8-2.2 \mathrm{~cm}$ range reported by Brownell and Ness (1970).

\section{Juvenile and Adult Diet}

The diet of $P$. blainvillei in northern Argentina was composed of 20 teleosts, 3 crustaceans and 2 cephalopod species, a wider prey spectrum than that of previous studies (Perez Macri, 1987; Bastida et al., 1992; Perez et al., 1996). The most important prey species were C. guatucupa, M. furnieri, $L$. sanpaulensis and $U$. brasiliensis.

The present study included franciscanas from two major habitats: an estuarine area, characterised by highly variable salinity, shallow and calm waters and soft bottom with high organic matter content; and a marine area, with high and more stable salinity, exposed beachfront and deeper sandy bottom with reduced organic content (Martin et al., 1999). Differences in diet between these habitats were sometimes not only qualitative, but also quantitative, as the same prey could have different distribution and abundance in these areas.

The estuarine diet was composed predominantly by $M$. furnieri followed by C. guatucupa, O. argentinensis and $M$. ancylodon, whereas the marine diet was dominated by $C$. guatucupa followed by L. sanpaulensis and $U$. brasiliensis. The shrimps A. longinaris and P. muelleri and the teleost Paralonchurus brasiliensis, which have not been found in the diet of franciscanas from Argentina in previous studies, are now reported as prey of Pontoporia in this area.

The inverse importance of C. guatucupa and M. furnieri found in estuarine or marine waters is mainly due to the biological characteristics of these species. C. guatucupa juveniles are distributed in high concentrations in the coastal marine area
(Cordo, 1986a; Cousseau et al., 1986), becoming easily available to Pontoporia. In the estuarine area (mainly in Bahía Samborombón) dense schools of juvenile M. furnieri are found during the first 2-3 years of life (Cotrina, 1986; Cousseau et al., 1986; Lasta, 1995; Nion, 1997; Macchi et al., 1996; Acha et al., 1999), becoming the main target species for franciscanas of this area. White croaker is the most important constituent of the Bahía Samborombón fish community, with numerical abundance and biomass representing nearly $80 \%$ and $65 \%$ respectively (Lasta, 1995). Both C. guatucupa and M. furnieri have reproductive peaks in spring and early summer, but whereas white croakers spawning concentrations are near the bottom salinity front in the inner part of the Rio de la Plata estuary, striped weakfish spawning area is close to the surface salinity front in the boundary with the open ocean (Macchi et al., 1996; Macchi, 1998; Macchi and Acha, 1998; Acha, 1999).

The dominance of C. guatucupa and, to a lesser degree, of M. furnieri, L. sanpaulensis and A. longinaris, coincide with the franciscana's diet reported by Praderi (1984) for Uruguay. Perez et al. (1996) recorded a low richness diet in franciscanas incidentally killed in marine waters off Puerto Quequén (Argentina), being also L. sanpaulensis the most important (IRI) of the nine prey species, followed by the horse mackerel, Trachurus lathami. The striking case of the midshipman, Porichthys porosissimus, and the large head hairtail, Trichiurus lepturus, are still the main difference in the diet of franciscanas from Uruguay and Argentina. $P$. porosissimus was one of the most important prey item in Uruguay (Fitch and Brownell, 1971; Praderi, 1984) and, although its distribution overlaps with that of franciscanas in Argentina, it has yet to be recorded as prey in this area. It is probable that feeding or spawning $P$. porosissimus concentrations are important in Uruguay, and very accessible to Pontoporia. The same seems to be the case of $T$. lepturus, absent in the diet of franciscanas in Argentina but frequently reported as prey in waters off Uruguay (Fitch and Brownell, 1971; Praderi; 1984). Temporal differences (circa 20-30 years) between the studies in Uruguay and Argentina might also explain the difference, pointing out the need to update feeding studies in some areas where franciscanas are frequently recorded.

The diet of franciscanas in northern Argentina is very similar to that reported for southern Brazil (Pinedo, 1982; Ott, 1994, 2000; Bassoi, 1997; Bassoi et al., 2000). There, the most important preys are C. guatucupa, P. brasiliensis, T. lepturus, $P$. porosissimus, $U$. brasiliensis, $M$. furnieri and L. sanpaulensis. However, a higher number of cephalopod species is recorded, including the octopuses, Argonauta nodosa and Eledone gaucha, and the squid, Loligo plei, which are not found in Argentina and Uruguay.

Bassoi (1997) and Bassoi et al. (2000) found that a lower number of prey species were reported in autumn, with a clear predominance of T. lepturus and a higher frequency of A. nodosa. Engraulids were more frequently found in winter. They conclude that no differences could be drawn in the diet of franciscanas from northern and southern Rio Grande do Sul State, Brazil, and that the franciscana was an 
opportunistic feeder. Unlike Pinedo (1982), no sex differences were detected in the predation of cephalopods. Pinedo (1997) reported no temporal qualitative differences in the diet of franciscanas from southern Brazil between 1976-1993.

Di Beneditto et al. (1998) reported that the teleost families Sciaenidae, Trichiuridae, Batrachoididae, Stromateidae, Ariidae, Clupeidae and Engraulidae occurred in $95 \%$ of the stomach contents of franciscanas from Rio de Janeiro (Brazil), whereas $87 \%$ of them consumed loliginid cephalopods. In Paraná (Brazil), Oliveira et al. (1998) found a total of 9 teleost families, with Isopisthus parvipinnis, Cynoscion microlepidotus, P. brasiliensis and Cetengraulis edentulus being the most frequent prey. The most important cephalopod was L. plei and, to a lesser extent, L. sanpaulensis.

Our results suggest that a minimum of ten stomachs is necessary to address the majority of the prey species of franciscanas from northern Argentina. Da Silva (1983) showed that, for Inia geoffrensis, 18 stomachs represented over $97 \%$ of the prey species reported and, for Sotalia fluviatilis, only $5 \%$ of new prey species were recorded after 12 stomachs had been analysed. Considering these results, caution should be taken when drawing conclusions from a limited number of stomach contents analysed.

The present study thus offers a more complete survey of the diet of Pontoporia in northern Argentina, with the analysis of both the lactation period and the diet of juveniles and adults. Gradual weaning was confirmed for Pontoporia, with early predation on crustaceans and fishes, whereas the lactation period was estimated to last 6-7 months. As reported for southern Brazil and Uruguay, franciscanas in northern Argentina prey on juvenile fish and small squids, being the target species basically the same in this area. The qualitative and quantitative differences between marine and estuarine habitats suggest that future studies should include a discrimination between samples of different habitats and environmental characteristics.

The effects of commercial fisheries are the main concern for the future of franciscanas in northern Argentina, as the most important fish prey (M. furnieri, C. guatucupa and $M$. ancylodon) showed early symptons of overfishing (Cordo, $1986 a ; b)$. A reduction in the occurence of $M$. furnieri and M. ancylodon in the diet of franciscanas from southern Brazil, as a probable consequence of stock depletion, was recently detected by Bassoi and Secchi (2000).

A comprehensive approach to franciscana conservation and management should include cooperative projects among researchers from Brazil, Uruguay and Argentina. In light of the results from this study, we recommend that dietary differences in these areas be re-examined and that the existing data on feeding be interpreted at the species levels, if possible. We also suggest that future reports on franciscana diet identification and quantification be standardised. These procedures will facilitate future assessments of energetic requirement of franciscanas and the evaluation of potential impacts on the stocks.

\section{Acknowledgements}

We acknowledge the kind cooperation of Viviana Quse and Alejandra Gomes D' Amaral during necropsies and sample processing. Facilities and equipment were kindly provided by Fundación Mundo Marino (San Clemente del Tuyú, Argentina). The present study was financed by grants from Academia de Ciencias de América Latina, Universidad Nacional de Mar del Plata (Projects 15/E005 and 15/E102) and Agencia Nacional de Promoción Científica y Tecnológica (PICT97 07-00000-01651 and PICT99 0107111) to Ricardo Bastida and Diego Rodríguez. CONICET (Argentina) granted a Doctoral Scholarship to Laura Rivero. The manuscript was considerably improved after reviews from Nélio Barros and Mariano Koen Alonso.

\section{References}

Acha, E.M. (1999) Estrategia reproductiva de la sacara, Brevoortia aurea (Spix E Agassiz, 1829), en el estuario del Río de la Plata. PhD Thesis. Universidad Nacional de Mar del Plata, Mar del Plata. 253pp.

Acha, E.M., Mianzan, H., Lasta, C., and Guerrero, R. (1999) Estuarine spawning of the whitemouth croaker (Micropogonias furnieri) in the Rio de la Plata, Argentina. Marine and Freshwater Research 50: 57-65.

Agresti, A. (1990) Categorical data analysis. John Wiley and Sons, New York.

Bassoi, M. (1997) Avaliação alimentar de toninhas, Pontoporia blainvillei (Gervais $\mathcal{E}$ d'Orbigny, 1844), capturadas incidentalmente na pesca costeira de emalhe, no sul do Rio Grande do Sul. BSc Dissertation. Fundação Universidade do Rio Grande, Rio Grande. 68pp.

Bassoi, M., Secchi, E.R., Santos, R.A. and Lucato, S.B. (2000) Avaliação da dieta alimentar de toninhas, Pontoporia blainvillei (Gervais \& d'Orbigny, 1844) capturadas acidentalmente na costa sul do Rio Grande do Sul. Pages 96-99 in UNEP/CMS (Eds) Report of the Third Workshop for Coordinated Research and Conservation of the Franciscana Dolphin (Pontoporia blainvillei) in the Southwestern Atlantic. UNEP/CMS, Bonn.

Bassoi, M. and Secchi, E.R. (2000) Temporal variation in the diet of franciscana, Pontoporia blainvillei (Cetacea, Pontoporiidae), as a consequence of fish stock depletion off southern Brazil. Technical Paper DT9 presented to the IV Workshop para a Coordenação da Pesquisa e Conservação da Franciscana, Pontoporia blainvillei, no Atlântico Sul Ocidental, 05-09 November 2000, Porto Alegre.

Bastida, R., Rodríguez, D., Moreno, V., Perez, A., Marcovecchio, J. and Gerpe, M. (1992) Varamientos de pequeños cetáceos durante el período 1984-1988 en el área de Mar del Plata (Provincia de Buenos Aires, Argentina). Pages 1-19 in Anales III Reunión de Trabajo de Especialistas en Mamíferos Marinos Acuáticos de América del Sur, 25-30 July 1988, Montevideo.

Bastida, R., Loureiro, J., Quse, V. and Rodríguez, D. (1996) Varamientos y rehabilitación de Pontoporia blainvillei en el sector norte de la Provincia de Buenos Aires (Argentina). Page 107 in Abstracts, VII Reunión de Trabajo de Especialistas en Mamíferos Acuáticos de América del Sur, 22-25 October 1996, Viña del Mar.

Bastida, R,. Rodríguez, D., Scarlato, N. and Favero, M. (in press) Marine biodiversity of the South-Western Atlantic Ocean and main environmental problems of the region in Miyazaki, N. (Ed.) Man and the ocean. United Nations University Press. Tokyo.

Brownell Jr., R.L. (1984) Review of the reproduction in platanistoid dolphins. Pages 149-158 in Perrin, W.F., Brownell Jr., R.L. and DeMaster, D.P. (Eds) Reproduction in whales, dolphins and porpoises. International Whaling Commission (special issue 6), Cambridge. 
Brownell Jr., R.L. (1989) Franciscana Pontoporia blainvillei (Gervais and d'Orbigny, 1844). Pages 45-67 in Ridgway, S. and Harrison, R. (Eds) Handbook of marine mammals, Vol 5: the first book of dolphins. Academic Press. New York.

Brownell Jr., R.L. and Ness, R. (1970) Preliminary notes on the biology of the franciscana dolphin, Pontoporia blainvillei (Cetacea, Platanistidae). Pages 23-28 in Proceedings, VI Annual Conference on Biological Sonar and Diving Mammals, Standford Research Institute, Palo Alto.

Burmeister, H. (1867) Preliminary observations on the anatomy of Pontoporia blainvillei. Proceedings of the Zoological Society of London 1867: 484-489.

Cabrera, A. and Yepes, J. (1940) Mamíferos Sud-Americanos. Historia Natural Ediar, Buenos Aires.

Caon, G. and Fialho, C.B. (1999) Morphometric measurements to estimate body fat condition in franciscana dolphin (Pontoporia blainvillei) in Rio Grande do Sul State, southern Brazil. Page 29 in Abstracts, XIII Biennial Conference on the Biology of Marine Mammals, 28 November - 03 December 1999, Maui.

Castley, J.G., Cockcroft, V.G. and Kerley, G.I. (1991) A note on the stomach contents of fur seals Arctocephalus pusillus pusillus beached on the South-East coast of South Africa. South African Journal of Marine Science 2: 573-577.

Corcuera, J. (1994) Incidental mortality of franciscanas in Argentine waters: the threat of small fishing camps. Pages 291-294 in Perrin, W.F., Donovan, G.P. and Barlow, J. (Eds) Gillnets and cetaceans. International Whaling Commission (special issue 15), Cambridge.

Cordo, H.D. (1986a) Estudios biológicos sobre peces costeros con datos de dos campañas de investigación realizadas en 1981. III Pescadilla de Red (Cynoscion striatus). Publicación de la Comisión Técnica Mixta Argentino-Uruguaya 1: 15-27.

Cordo, H.D. (1986b) Estudios biológicos sobre peces costeros con datos de dos campañas de investigación realizadas en 1981. IV Pescadilla Real (Macrodon ancylodon). Publicación de la Comisión Técnica Mixta Argentino-Uruguaya 1: 47-52.

Cortés, E. (1997) A critical review of methods of studying fish feeding based on analysis of stomach contents: application to elasmobranch fishes. Canadian Journal of Fisheries and Aquatic Sciences 54: 726-738.

Cotrina, C.P. (1986) Estudios biológicos sobre peces costeros con datos de dos campañas de investigación realizadas en 1981. II Corvina Rubia (Micropogonias furnieri). Publicación de la Comisión Técnica Mixta Argentino-Uruguaya 1: 8-14.

Cousseau, M.B., Cotrina, C.P., Cordo, H.D. and Burgos, G.E. (1986) Análisis de datos biológicos de la corvina rubia (Micropogonias furnieri) y pescadilla de red (Cynoscion striatus) obtenidos en dos campañas del año 1983. Publicación de la Comisión Técnica Mixta Argentino-Uruguaya 1: 319-332

Danilewicz, D. and Secchi, E.R. (2000) Reprodução em fêmeas de toninha, Pontoporia blainvillei, no Rio Grande do Sul. Technical Paper DT23 presented to the IV Workshop para a Coordenação da Pesquisa e Conservação da Franciscana, Pontoporia blainvillei, no Atlântico Sul Ocidental, 05-09 November 2000, Porto Alegre.

Da Silva, V. (1983) Ecologia alimentar dos golfinhos da Amazônia. MSc Thesis. Fundação Universidade do Amazonas, Manaus. 118pp.

Di Beneditto, A.P. and Ramos, R.A. (2000). Pontoporia blainvillei (Gervais $\mathcal{E}$ d'Orbigny, 1844) in the northern Rio de Janeiro State $\left(21^{0} 18^{\prime} S-22^{\circ} 25^{\prime} S\right)$, Brazil. Technical Paper DT11 presented to the IV Workshop para a Coordenação da Pesquisa e Conservação da Franciscana, Pontoporia blainvillei, no Atlântico Sul Ocidental, 05-09 November 2000, Porto Alegre.

Di Beneditto, A.P., Ramos, R., Lima, N.R. and Santos, R.A. (1998) Feeding ecology of Pontoporia blainvillei and Sotalia fluviatilis in northen Rio de Janeiro, Brazil: a preliminary analysis. Page 66 in Abstracts, VII Reunião de Trabalho de Especialistas em Mamíferos Aquáticos da América do Sul, 2529 October 1998, Olinda.
Fitch, J.E. and Brownell Jr., R.L. (1971) Food habits of the franciscana Pontoporia blainvillei (Cetacea: Platanistidae) from South America. Bulletin of Marine Science 21: 626-636.

Gannon, D.P., Craddock, J.E. and Read, A.J. (1998) Autumn food habits of harbour porpoises, Phocoena phocoena, in the Gulf of Maine. Fishery Bulletin 96: 428-437.

Gerpe, M., Rodríguez, D., Moreno, V., Bastida, R., and de Moreno, J. (2002) Accumulation of heavy metals in the franciscana (Pontoporia blainvillei) from Buenos Aires Province, Argentina. The Latin American Journal of Aquatic Mammals (special issue) 1: 95-106.

Harrison, R.J., Bryden, M.M., McBreaty, D.A. and Brownell Jr., R.L. (1981) The ovaries and reproduction in Pontoporia blainvillei (Cetacea: Platanistidae). Journal of Zoology 193: 563-580.

Kamiya, T. and Yamasaki, F. (1974) Organ weights of Pontoporia blainvillei and Platanista gangetica (Platanistidae). Scientific Reports of the Whales Research Institute 26: 265-270.

Kasuya, T. and Brownell Jr., R.L. (1979) Age determination, reproduction, and growth of franciscana dolphin, Pontoporia blainvillei. Scientific Reports of the Whales Research Institute 31: 45-67.

Koen-Alonso, M., Crespo, E.A., Garcia, N.A., Pedraza, S.N. and Coscarella, M. (1998) Diet of dusky dolphins, Lagenorhynchus obscurus, in waters off Patagonia, Argentina. Fishery Bulletin 96: 366-374.

Lahille, F. (1905) Las ballenas de nuestros mares. Revista del Jardín Zoológico de Buenos Aires 1: 28-82.

Lasta, C.A. (1995) La Bahía Samborombón: zona de desove y crianza de peces. PhD Thesis. Universidad Nacional de La Plata, La Plata. 304pp.

Le Cren, E.D. (1951) The length-weigth relationship and seasonal cycles in gonad weigth and condition in the perch (Perca fluviatilis). Journal of Animal Ecology 20: 201-219.

Leta, H. (1987) Contribución al conocimiento de la alimentación de la pescadilla de red (Macrodon ancylodon). Frente Marítimo 3: 77-78.

Loureiro, J.D., Bastida, R., Quse, V., Costa, F., Rodríguez, D. and Ruoppollo, V. (1996) Rehabilitación y reintroducción de mamíferos marinos a través de la Fundación Mundo Marino (San Clemente del Tuyú, Argentina). Page 108 in Abstracts, VII Reunión de Trabajo de Especialistas en Mamíferos Acuáticos de América del Sur, 22-25 October 1996, Viña del Mar.

Macchi, G.J. (1998) Preliminary estimate of the spawning frequency and batch fecundity of the striped weakfish, Cynoscion striatus, in the coastal waters off Buenos Aires province. Fishery Bulletin 96: 375-381.

Macchi, G.J. and Acha, E.M. (1998) Aspectos reproductivos de las principales especies de peces de la Zona Común de Pesca y en El Rincón. Pages 67-89 in Lasta, C.A. (Ed.) Resultados de una campaña de evaluación de recursos demersales costeros de la Provincia de Buenos Aires. Informe Técnico del Instituto Nacional de Investigación y Desarrollo Pesquero 21, Mar del Plata.

Macchi, G.J., Acha, E.M. and Lasta, C.A. (1996) Desove y fecundidad de la corvina rubia, Micropogonias furnieri Desmarest, 1823, del Estuario del Río de la Plata, Argentina. Boletín del Instituto Español de Oceanografía 12: 99-113.

Martin, J.P., Bastida, R., Ieno, E. and Trassens, M. (1999) Estudio sobre el biofouling de los humedales del estuario del Río de La Plata (Argentina). Pages 668-669 in Extended Abstracts, VIII Congreso Latinoamericano de Ciencias del Mar, II, 17-21 October 1999, Trujillo.

Nion, H. (1997) Fishes of the Rio de la Plata and some aspects of their ecology. Pages 163-184 in Wells, P.G. and Daborn, G.R. (Eds) The Rio de la Plata: an environmental overview. An Eco-Plata Project Background Report. Dalhousie University, Halifax. 
Norris, K.S. (1961) Standarized methods for measuring and recording data on small cetaceans. Journal of Mammalogy 42: 471-476.

Oliveira, M.R., Pinheiro, P.C. and Rosas, F.C.W. (1998) Ecologia alimentar de Sotalia fluviatilis e Pontoporia blainvillei acidentalmente capturados no litoral do Paraná. Page 145 in Abstracts, VIII Reunião de Trabalho de Especialistas em Mamíferos Aquáticos da América do Sul, 25-29 October 1998, Olinda.

Ott, P.H (1994) Estudo da ecologia alimentar de Pontoporia blainvillei (Gervais E d'Orbigny, 1844) (Cetacea, Pontoporiidae) no litoral norte do Rio Grande do Sul, sul do Brasil. BSc Dissertation. Universidade Federal do Rio Grande do Sul, Porto Alegre. 69pp.

Ott, P.H. (2000) Diet of the franciscana dolphins, Pontoporia blainvillei, in the northern Rio Grande do Sul State, Southern Brazil. Pages 93-95 in UNEP/CMS (Eds) Report of the Third Workshop for Coordinated Research and Conservation of the Franciscana Dolphin (Pontoporia blainvillei) in the Southwestern Atlantic. UNEP/CMS, Bonn.

Perez, J., Gingarelli, M., Beilis, A. and Corcuera, J. (1996) Alimentación del delfín franciscana en el Sur de la Provincia de Buenos Aires, Argentina. Page 91 in Abstracts, VII Reunión de Trabajo de Especialistas en Mamíferos Acuáticos de América del Sur, 2225 October 1996, Viña del Mar.

Perez-Macri, G. (1987) Resultados preliminares del estudio de alimentación de Pontoporia blainvillei en aguas costeras argentinas. Page 107 in Abstracts, II Reunião de Trabalho de Especialistas em Mamíferos Aquáticos da América do Sul, 4-8 August 1986, Rio de Janeiro.

Pierce, G.J. and Boyle, P.R. (1991) A review of methods for diet analysis in piscivorous marine mammals. Oceanography and Marine Biology Annual Review 29: 409-486.

Pineda, S.E., Aubone, A. and Brunetti, N.E. (1996) Identificación y morfometría comparada de las mandíbulas de Loligo gahi y Loligo sanpaulensis (Cephalopoda, Loliginidae) del Atlántico Sudoccidental. Revista de Investigación y Desarrollo Pesquero 10: 85-99.

Pinedo, M.C. (1982) Análises dos conteúdos estomacais de Pontoporia blainvillei (Gervais $\mathcal{E}$ d'Orbigny, 1844) e Tursiops gephyreus (Lahille, 1908) (Cetacea, Platanistidae e Delphinidae) na zona estuarial e costeira de Rio Grande, RS, Brasil. MSc Thesis. Fundação Universidade do Rio Grande, Rio Grande. 95pp.

Pinedo, M.C. (1994) Review of the status and fishery interactions of the franciscana, Pontoporia blainvillei, and other small cetaceans of the southern Brazil. Pages 251-259 in Perrin,
W.F, Donovan, G.P. and Barlow, J. (Eds) Gillnets and cetaceans. International Whaling Commission (special issue 15), Cambridge.

Pinedo, M.C. (1997) Relatório do $2^{\circ}$ Encontro. Pages 1-7 in Pinedo, M.C and Barreto, A.S. (Eds) Anais do $2^{\circ}$ Encontro sobre Coordenação de Pesquisa e Manejo da Franciscana. Ed. FURG, Rio Grande.

Pinedo, M.C., Praderi, R. and Brownell Jr., R.L. (1989) Review of the Biology and Status of the Franciscana, Pontoporia blainvillei. Pages 46-51 in Perrin, W.F., Brownell Jr., R.L., Kaiya, Z. and Jiankang, L. (Eds) Biology and conservation of the river dolphins. Occasional Papers IUCN, 3. Gland.

Pinedo, M.C. and Hohn, A.A. (2000) Growth layer patterns in teeth from the Franciscana, Pontoporia blainvillei: developing a model for precision in age estimation. Marine Mammal Science 16: 1-27.

Pinkas, L., Oliphan, M.S. and Iverson, I.L.K. (1971) Food habits of albacore, bluefin tuna and bonito in Californian waters. California Fish and Game 152: 1-105

Praderi, R. (1984) Mortalidad de franciscana, Pontoporia blainvillei, en pesquerías artesanales de tiburón en la costa atlántica uruguaya. Revista del Museo Argentino de Ciencias Naturales "Bernardino Rivadavia", Zoología XIII: 259-272.

Praderi, R. (1986) Comentarios sobre la distribución de Pontoporia blainvillei en aguas del Rio de La Plata. Pages 206-214 in Actas de la I Reunión de Trabajo de Expertos en Mamíferos Acuáticos de América del Sur, 24-29 June 1984, Buenos Aires.

Praderi, R., Pinedo, M.C and Crespo, E.A. (1989) Conservation and management of Pontoporia blainvillei in Uruguay, Brazil and Argentina. Pages 52-56 in Perrin, W.F., Brownell Jr., R.L., Kaiya, Z. and Jiankang, L. (Eds) Biology and conservation of the river dolphins. Occasional Papers IUCN, 3. Gland.

Sanchez, F., Marí, N., Lasta, C. and Giangiobbe, A. (1991) Alimentación de la Corvina Rubia (Micropogonias furnieri) en la Bahía Samborombón. Frente Marítimo 8: 43-50.

Secchi, E.R., Zerbini, A.N., Bassoi, M., Dalla Rosa, L., Möller, L.M. and Rocha-Campos, C.C. (1997) Mortality of franciscanas, Pontoporia blainvillei, in coastal gillnetting in southern Brazil. Report of the International Whaling Commission 47: 653-658.

Smith, R.J. and Read, A.J. (1992) Consumption of euphausiids by harbor porpoise (Phocoena phocoena) calves in the Bay of Fundy. Canadian Journal of Zoology 70: 629-632.

Zar, J.H. (1984) Biostatistical Analysis. Prentice Hall Inc., Englewood Cliffs. 


\section{APPENDIX I}

List of prey species found in franciscanas from northern Argentina. English, Spanish and Portuguese common names are in brackets.

FISH

Class Osteichthyes

Order Clupeiformes

Family Engraulidae

Engraulis anchoita Hubbs and Marini, 1935

Anchoa marinii Hildebrand, 1943

Family Clupeidae

ycengraulis grossidens (Aggassiz, 1829)

Order Gadiformes

Ramnogaster arcuata (Jenyns, 1842)

(Argentine anchovy, Anchoíta, Anchoita)

(Anchovy, Anchoa, Manjubinha)

(River anchovy, Anchoita de Río)

(Mojarrita)

Family Phycidae

Order Ophidiiformes

$$
\text { Urophycis brasiliensis (Kaup, 1858) (Brazilian codling, Brótola, Abrótea) }
$$

Order Atheriniformes

Raneya fluminensis Miranda Ribeiro, $1903 \quad$ (Raneya)

Family Atherinidae

Odonthestes argentinensis (Valenciennes,1835)

Order Sygnathiformes

Family Syngnathidae

Order Perciformes

Leptonotus blainvilleanus Eydoux and Gervais, 1837 (Piperfish, Aguja)

Family Pomatomidae

Pomatomus saltatrix (Linné, 1758) (Bluefish, Anchoa de Banco, Enchova)

Family Carangidae

Trachurus lathami Nichols, $1920 \quad$ (Rough scad, Surel, Xixarro)

Family Sparidae

Sparus pagrus Linné, 1758

Family Scienidae

Cynoscion guatucupa (Cuvier, 1830)

Macrodon ancylodon Schneider, 1801

Micropogonias furnieri (Desmarest, 1823)

Paralonchurus brasiliensis (Steindachner, 1875)

Pogonias cromis (Linné, 1766)

Umbrina canosai Berg, 1895

Family Mugilidae

Mugil platanus Gunther, 1880

Family Percophidae

Percophis brasiliensis Quoy and Gaymard, 1824

Family Stromateidae

Stromateus brasiliensis Fowler, 1906

(Red porgy, Besugo)

(Striped weakfish, Pescadilla de Red, Pescada Olhuda) (King weakfish, Pescadilla Real, Pescadinha)

(White croaker, Corvina Rubia, Corvina)

(Drum, Córvalo, Maria Luiza)

(Black drum, Corvina Negra, Miraguaia)

(Argentine croaker, Pargo Blanco, Castanha)

(Mullet, Lisa, Tainha)

(Brazilian flathead, Pez Palo, Tira-vira)

(Butterfish, Palometa Moteada, Pampo-pintado)

\section{CRUSTACEANS}

Class Malacostraca (SubClass Eumalacostraca, SuperOrder Eucarida)

$$
\text { Order Decapoda }
$$

Family Paneidae

Artemesia longinaris Bate, 1888

Family Solenoceridae

Pleoticus muelleri (Bate, 1888)

Family Sergestidae

Peisos petrunkevitchi Burkenroad, 1945

Order Mysidacea

Family Mysidae

Neomysis americana (Smith 1873)

(Argentine stiletto shrimp Camarón, Camarão Serrinha)

(Argentine red shrimp, Langostino, Camarão Santana)

(Shrimp, Camaroncito)

(Mysid)

MOLLUSKS

Class Cephalopoda

Order Teuthoidea

Family Loliginidae

Loligo sanpaulensis Brakoniecki, 1984

Order Octopoda

Family Octopodidae

Octopus tehuelchus D'Orbigny, 1834

(Longfin inshore squid, Calamarete, Lula)

(Tehuelche octopus, Pulpito, Polvo)

Received 10 February 2002. Accepted 18 May 2002. 